ORNL/ER-383

Energy Systems Environmental Restoration Program

\title{
Contingency Plan for the Old Hydrofracture \\ Facility Tanks Sluicing Project at Oak Ridge National Laboratory, Oak Ridge, Tennessee
}

Date Issued-October 1996

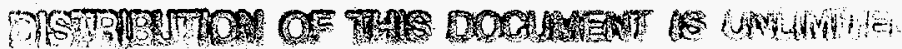

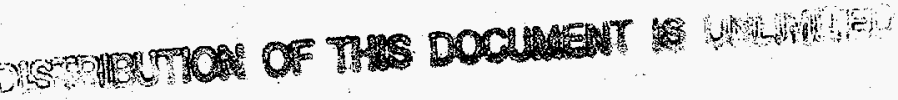

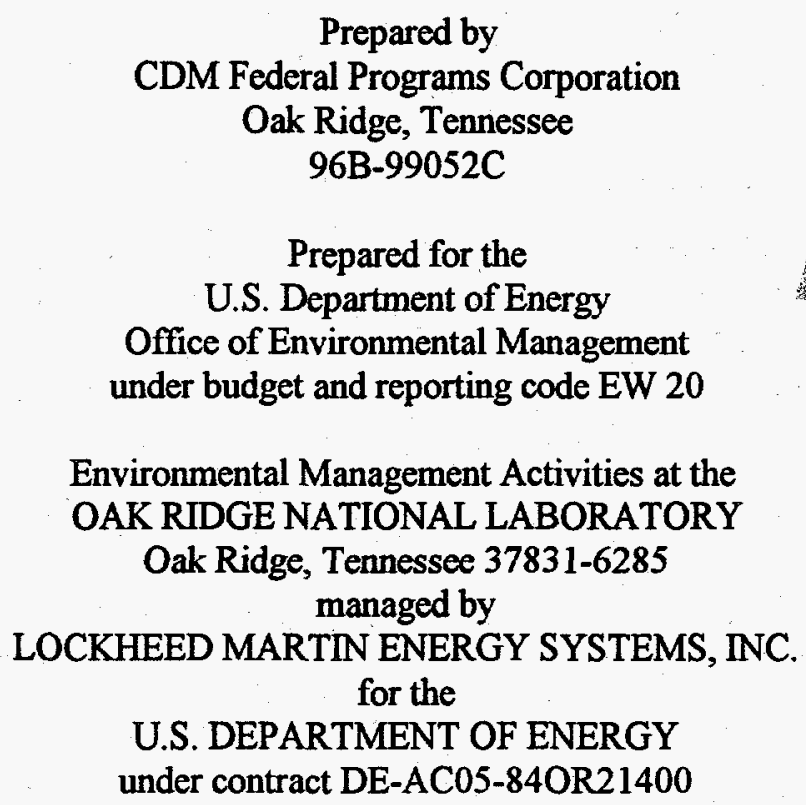

Environmental Management Activities at the

OAK RIDGE NATIONAL LABORATORY

Oak Ridge, Tennessee 37831-6285

managed by

LOCKHEED MARTIN ENERGY SYSTEMS, INC.

for the

U.S. DEPARTMENT OF ENERGY

under contract DE-AC05-84OR21400 


\section{DISCLAIMER}

This report was prepared as an account of work sponsored by an agency of the United States Government. Neither the United States Government nor any agency thereof, nor any of their employees, makes any warranty, express or implied, or assumes any legal liability or responsibility for the accuracy, completeness, or usefulness of any information, apparatus, product, or process disclosed, or represents that its use would not infringe privately owned rights. Reference herein to any specific commercial product, process, or service by trade name, trademark, manufacturer, or otherwise does not necessarily constitute or imply its endorsement, recommendation, or favoring by the United States Government or any agency thereof. The views and opinions of authors expressed herein do not necessarily state or reflect those of the United States Government or any agency thereof. 


\section{DISCLAIMER}

Portions of this document may be illegible in electronic image products. Images are produced from the best available original document. 


\section{PREFACE}

This Contingency Plan for the Old Hydrofracture Facility Tanks Sluicing Project at the Oak Ridge National Laboratory, Oak Ridge Tennessee (ORNL/ER-383) was prepared under Work Breakdown Structure 6.1.05.20.01.17.10, ADS 3305, CCADS 3328, "Old Hydrofracture Facility Tanks Content Removal," which is being conducted under the Comprehensive Environmental Response, Compensation, and Liability Act. This document outlines plans for preventing, detecting, and mitigating potential accident/release scenarios during the planned removal action. It is based on the preliminary engineering design for the project, which is presented in the Preliminary Engineering Report, Old Hydrofracture Facility Tanks Content Removal Project (Energy Systems 1996c). 



\section{CONTENTS}

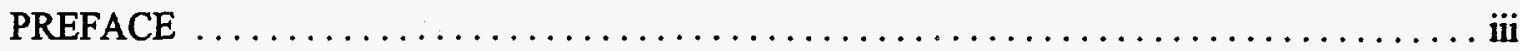

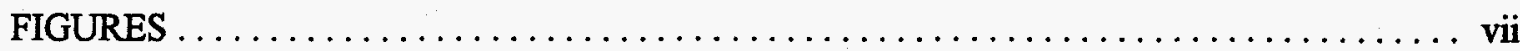

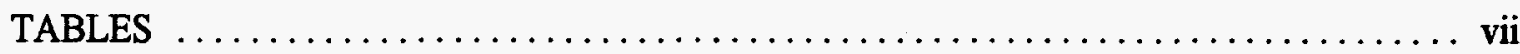

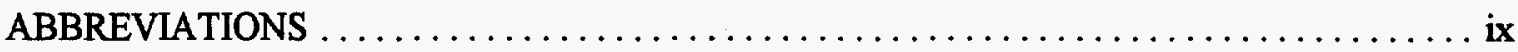

EXECUTIVE SUMMARY $\ldots \ldots \ldots \ldots \ldots \ldots \ldots \ldots \ldots \ldots \ldots \ldots \ldots \ldots \ldots \ldots \ldots \ldots$

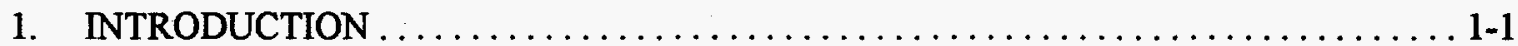

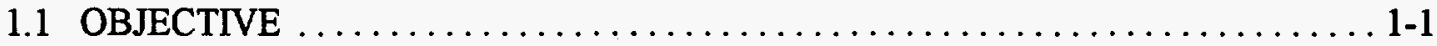

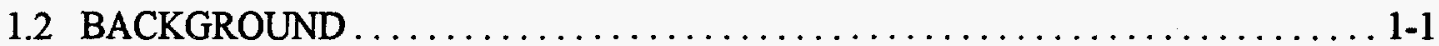

2. SITE DESCRIPTION AND ENVIRONMENTAL SETTING $\ldots \ldots \ldots \ldots \ldots \ldots \ldots \ldots 2-1$

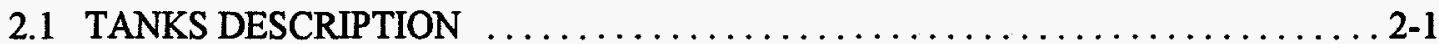

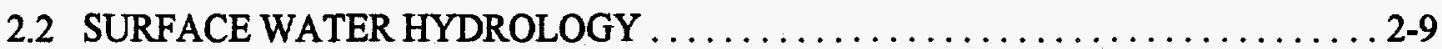

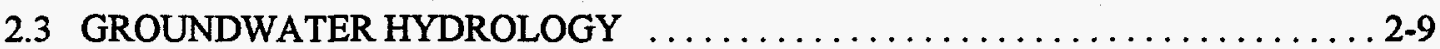

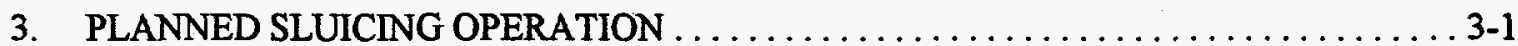

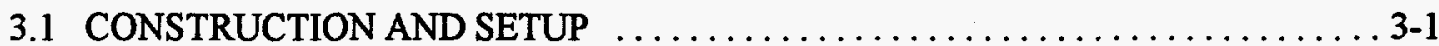

3.2 TANK SLUICING AND WASTE TRANSFER $\ldots \ldots \ldots \ldots \ldots \ldots \ldots \ldots \ldots . . \ldots \ldots$

3.3 EQUIPMENT DISMANTLING AND DECONTAMINATION $\ldots \ldots \ldots \ldots \ldots \ldots . . .4$

4. ACCIDENT/RELEASE SCENARIOS $\ldots \ldots \ldots \ldots \ldots \ldots \ldots \ldots \ldots \ldots \ldots \ldots \ldots$ 4-1

4.1 OVERVIEW OF ACCIDENT/RELEASE SCENARIOS $\ldots \ldots \ldots \ldots \ldots \ldots \ldots \ldots$ 4-1

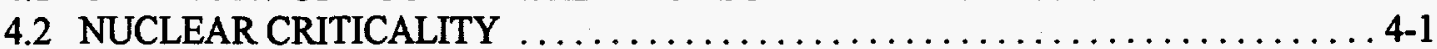

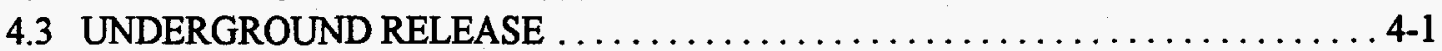

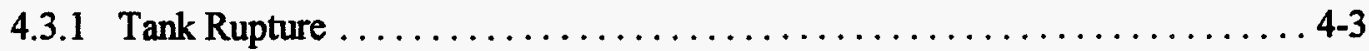

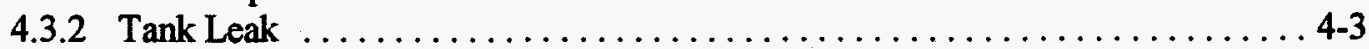

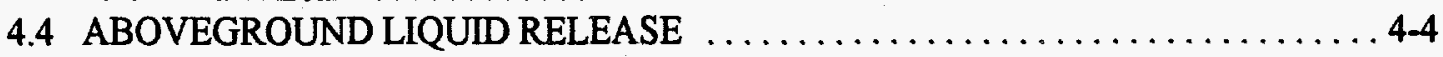

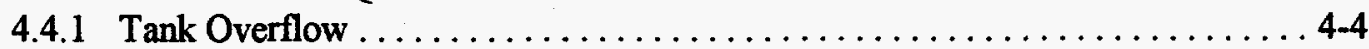

4.4.2 Waste Transfer Pipeline Rupture or Leak ................ $\ldots .4$

4.4.3 Leak from Operating Sluice Equipment ................. 4.5

4.4.4 Spill from Sluice Equipment During Maintenance or Transfer Between Tanks . 4-5

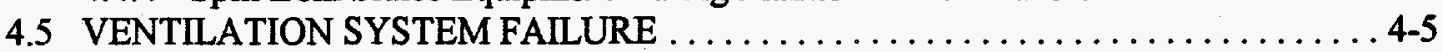

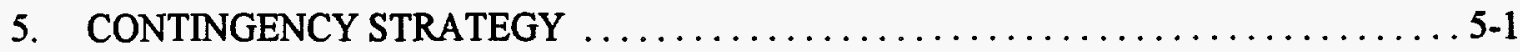

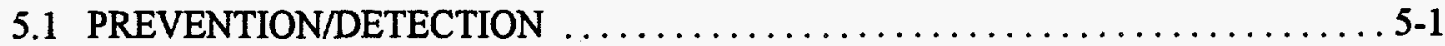

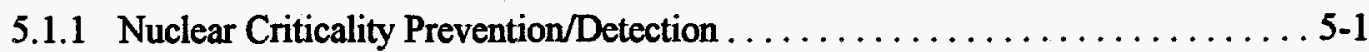

5.1 .2 Underground Release Prevention/Detection $\ldots \ldots \ldots \ldots \ldots \ldots \ldots \ldots \ldots$ 5-1

5.1.3 Tank Overflow Prevention/Detection ..................... 5-2

5.1.4 Waste Transfer Pipeline Leak Prevention/Detection $\ldots \ldots \ldots \ldots \ldots \ldots .5$ 5-3

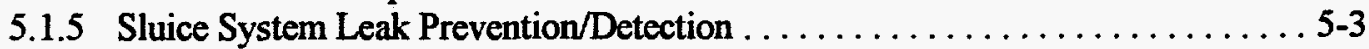

5.1.6 Ventilation System Failure Prevention/Detection $\ldots \ldots \ldots \ldots \ldots \ldots \ldots .54$ 


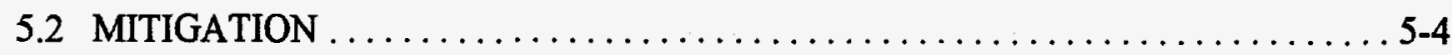

5.2 .1 Nuclear Criticality Mitigation $\ldots \ldots \ldots \ldots \ldots \ldots \ldots \ldots \ldots \ldots \ldots \ldots, 5,4$

5.2 .2 Underground Release Mitigation $\ldots \ldots \ldots \ldots \ldots \ldots \ldots \ldots \ldots \ldots \ldots, 5,6$

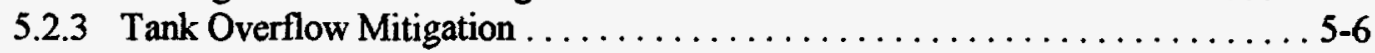

5.2.4 Waste Transfer Pipeline Leak Mitigation .................... 5-7

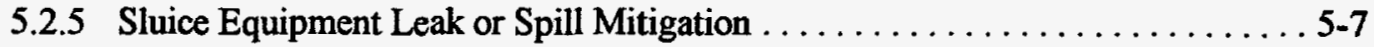

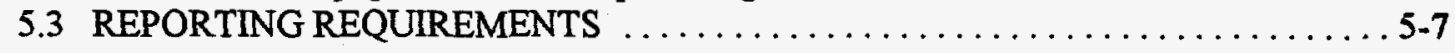

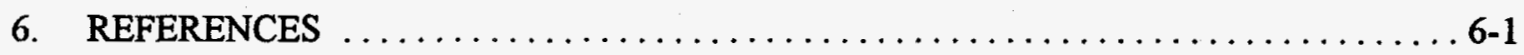

Appendix A: CALCULATED HOLDING CAPACITIES OF OHF TANK

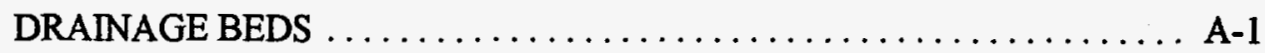




\section{FIGURES}

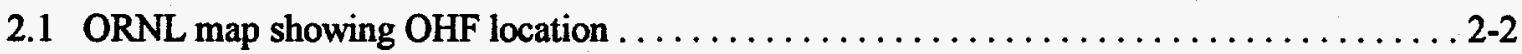

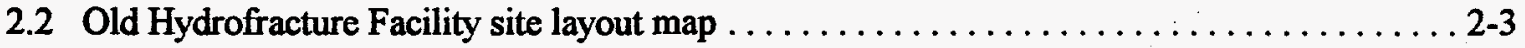

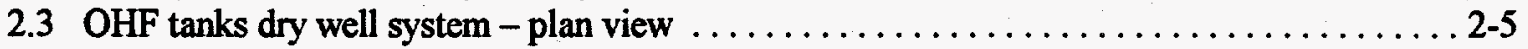

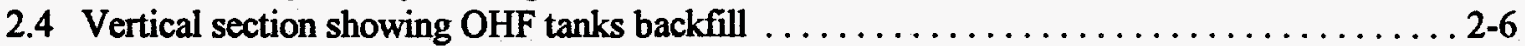

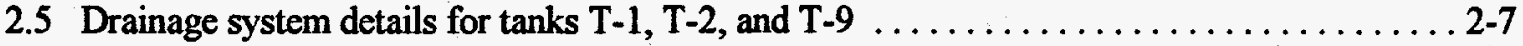

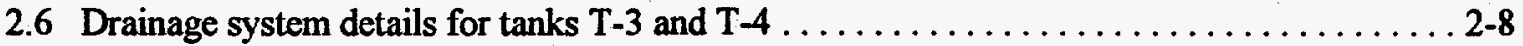

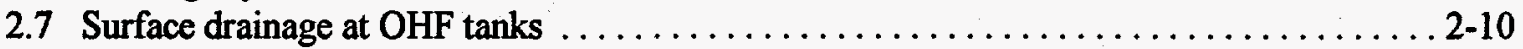

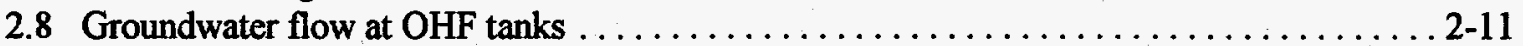

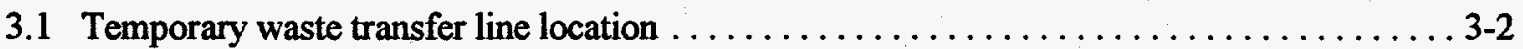

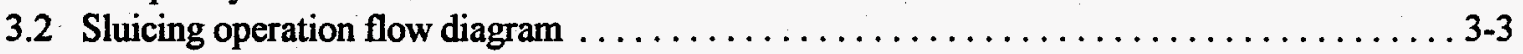

\section{TABLES}

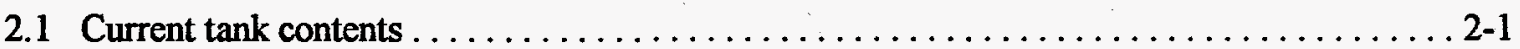

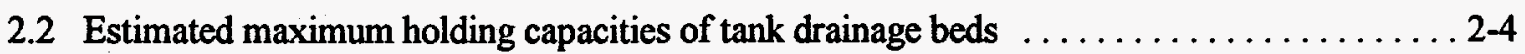

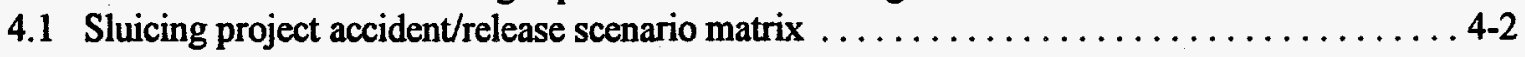

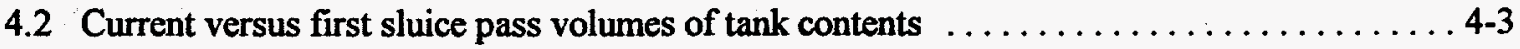

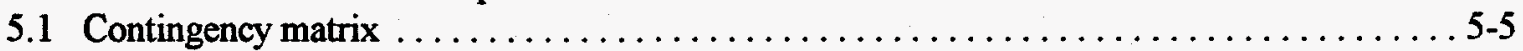

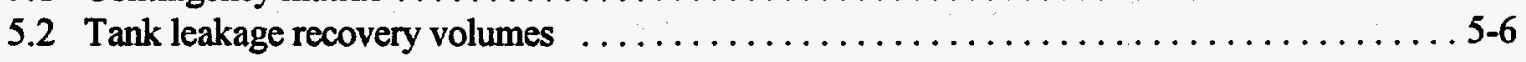





\section{ABBREVIATIONS}

CFR

DOP

Energy Systems

HEPA

LLLW

MVST

OHF

ORNL

NCSA

WAG

WMRAD
Code of Federal Regulations

dioctyl phthalate

Lockheed Martin Energy Systems, Inc.

high-efficiency particulate air

liquid low-level waste

Melton Valley Storage Tanks

Old Hydrofracture Facility

Oak Ridge National Laboratory

Nuclear Criticality Safety Approval

Waste Area Grouping

Waste Management and Remedial Action Division 


\section{EXECUTIVE SUMMARY}

Lockheed Martin Energy Systems, Inc. (Energy Systems), plans to begin a sluicing (flushing) and pumping project to remove the contents from five inactive, underground storage tanks at the Old Hydrofracture Facility (OHF) at the Oak Ridge National Laboratory (ORNL) in Oak Ridge, Tennessee. The tank contents will be transferred to the Melton Valley Storage Tanks, which are part of the active waste treatment system at ORNL. The purpose of the project is to minimize the risk of leaking the highly radioactive material to the environment.

The five OHF tanks each contain a layer of sludge and a layer of supernatant. Based on a sampling project undertaken in 1995, the sludge in the tanks has been characterized as transuranic and mixed waste and the supernatants have been characterized as mixed waste. The combined radioactivity of the contents of the five tanks is approximately $29,500 \mathrm{Ci}$.

This contingency plan is based on the preliminary design for the project [see Preliminary Engineering Report, Old Hydrofracture Facility Tanks Content Removal Project (Energy Systems 1996c)] and describes a series of potential accident/release scenarios for the project. It outlines Energy Systems' preliminary plans for prevention, detection, and mitigation. Prevention/detection methods range from using doubly contained pipelines to alarmed sensors and automatic pump cutoff systems. Plans for mitigation range from pumping leaked fluids from the built-in tank drainage systems and cleaning up spilled liquids to personnel evacuation. 


\section{INTRODUCTION}

The Old Hydrofracture Facility (OHF), located within Waste Area Grouping (WAG) 5 at the Oak Ridge National Laboratory (ORNL), includes five underground storage tanks that have been inactive since 1980. The five tanks contain a total of $42,000 \mathrm{gal}$ of liquid low-level waste (LLLW), consisting of approximately 36,000 gal of liquid and approximately 6,000 gal of sludge. On the basis of sampling projects carried out in 1988 and 1995-96, the tank contents have been characterized as mixed and transuranic waste. The radioactivity exhibited by the contents of the five tanks combined is approximately $29,500 \mathrm{Ci}$, most of which is contained within the sludge.

Lockheed Martin Energy Systems, Inc. (Energy Systems), is preparing to transfer the contents of the inactive OHF tanks to the active ORNL LLLW system, specifically, to the Melton Valley Storage Tanks (MVST). The Preliminary Engineering Report, Old Hydrofracture Facility Tanks Content Removal Project (Energy Systems 1996c) describes the technology that will be used to remove the tank contents. Briefly, a sluicing system will be used to resuspend the sludges in the liquid phase and the liquid will be pumped from the OHF tanks to the MVST. Site preparation work, including some structural modifications to the tanks, is in progress.

\subsection{OBJECTIVE}

The objective of this contingency plan is to discuss possible scenarios in which the radioactively contaminated contents of the OHF tanks might be released to the environment during the sluicing and pumping process and to describe methods of preventing, detecting, and mitigating any such release. It is based on the preliminary engineering design for the project.

\subsection{BACKGROUND}

The OHF was built in 1963 to dispose of liquid waste by mixing it with grout and injecting it into a shale formation located approximately $1,000 \mathrm{ft}$ below the ground surface. The five underground tanks were used to temporarily store liquid waste before mixing and injection. In addition to the five tanks considered in this report, the OHF includes Buildings 7852 and 7853, a pump house, storage silos, waste pits, a retention pond, and various support equipment and apparatus. The facility began operation in 1964 and was shut down in 1980 . Since that time it has been maintained in a safe storage mode. Additional information regarding facility operation is included in the Site Characterization Summary Report for the Old Hydrofracture Facility, Waste Area Grouping 5, at Oak Ridge National Laboratory, Oak Ridge, Tennessee (Energy Systems 1996d).

Before initiating site preparation work for the sluicing and pumping project, Energy Systems evaluated the condition of the tanks to determine whether the stresses imposed by the site work and the sluicing could be sustained by the tanks without collapse and release of the contents. The evaluation included several components:

- video inspection of interior of tanks (January 1996), 
- $\quad$ structural analysis using the methodology outlined in "A Method for Evaluating the Structural Integrity of Buried Liquid Low-Level Waste Tanks" (Kincaid 1993) and a computer-aided finite element program (ABAQUS Version 5.5), and

- measurement of coupons cut from tanks during installation of new risers (September 1996).

The results of the analyses are reported in the Preliminary Engineering Report, Old Hydrofracture Facility Tanks Content Removal Project (Energy Systems 1996c), and Structural Integrity Assessment for Installation of Tank Risers at the Old Hydrofracture Tanks (STEP in preparation). The conclusion drawn from the evaluation was that the tank wall integrity is probably sufficient to support the planned project and that the likelihood of tank rupture is highly unlikely. 


\section{SITE DESCRIPTION AND ENVIRONMENTAL SETTING}

The OHF is located on the Oak Ridge Reservation approximately $1 / 2$ mile south of WAG 1 (Fig. 2.1). Access to this area is restricted from the general public.

\subsection{TANKS DESCRIPTION}

The five OHF tanks are buried underground, approximately $110 \mathrm{ft}$ west of Building 7852 and approximately 131 yd east of White Oak Creek. The tanks lie parallel to each other in a north/south orientation (see Fig. 2.2).

Tanks T-1 and T-2 are 15,000-gal tanks, measuring $8 \mathrm{ft}$ in diameter and $44.1 \mathrm{ft}$ in length. Tank $\mathrm{T}-9$ is a 13,000 -gal tank, measuring $10 \mathrm{ft}$ in diameter and $23.8 \mathrm{ft}$ in length. Tanks T-3 and T-4 are 25,000 -gal tanks, measuring $10.5 \mathrm{ft}$ in diameter and $23.8 \mathrm{ft}$ in length. None of the tanks is currently full. Table 2.1 shows the current volume of liquid and sludge in each tank, compared to its capacity.

Table 2.1. Current tank contents

\begin{tabular}{ccccc}
\hline Tank & $\begin{array}{c}\text { Current liquid } \\
\text { volume } \\
\text { (gal) }\end{array}$ & $\begin{array}{c}\text { Current sludge } \\
\text { volume } \\
\text { (gal) }\end{array}$ & $\begin{array}{c}\text { Current total } \\
\text { volume } \\
\text { (gal) }\end{array}$ & $\begin{array}{c}\text { Capacity } \\
\text { (gal) }\end{array}$ \\
\hline $\mathrm{T}-1$ & 7,650 & 800 & 8,450 & 15,000 \\
$\mathrm{~T}-2$ & 9,500 & 1,200 & 10,700 & 15,000 \\
$\mathrm{~T}-9$ & 4,650 & 500 & 5,150 & 13,000 \\
$\mathrm{~T}-3$ & 1,100 & 2,050 & 3,150 & 25,000 \\
$\mathrm{~T}-4$ & 13,350 & 1,350 & 14,700 & 25,000 \\
\hline
\end{tabular}

The OHF tanks were installed at the facility in two stages. Tanks T-1, T-2, and T-9, which are made of carbon steel and unlined, were installed as part of the original OHF construction, circa 1963. Tanks T-3 and T-4, which are rubber-lined carbon steel, were added in 1966 . All five of the tanks were previously used elsewhere on the Oak Ridge Reservation and were refitted for use in the OHF system.

Tanks T-1, T-2, and T-9 are buried together in a single pit. Four-ft-high, 8-in.-thick concrete block walls separate the pit into three cells, one for each tank. Each cell is drained separately through a 6-in. perforated vitreous clay pipe into a 12 -in. dry well. Each dry well has a (nonperforated) 6-in. vitreous clay outlet pipe that exits the well approximately $2 \mathrm{ft}$ above the bottom of the excavation and extends south to the slope north of the facility access road. The outlets for the T-1 and T-2 dry wells are enclosed together in an uncovered concrete box on the slope. The outlet for the T-9 dry well is enclosed in a separate concrete box. Each outlet is fitted with a shutoff valve. 


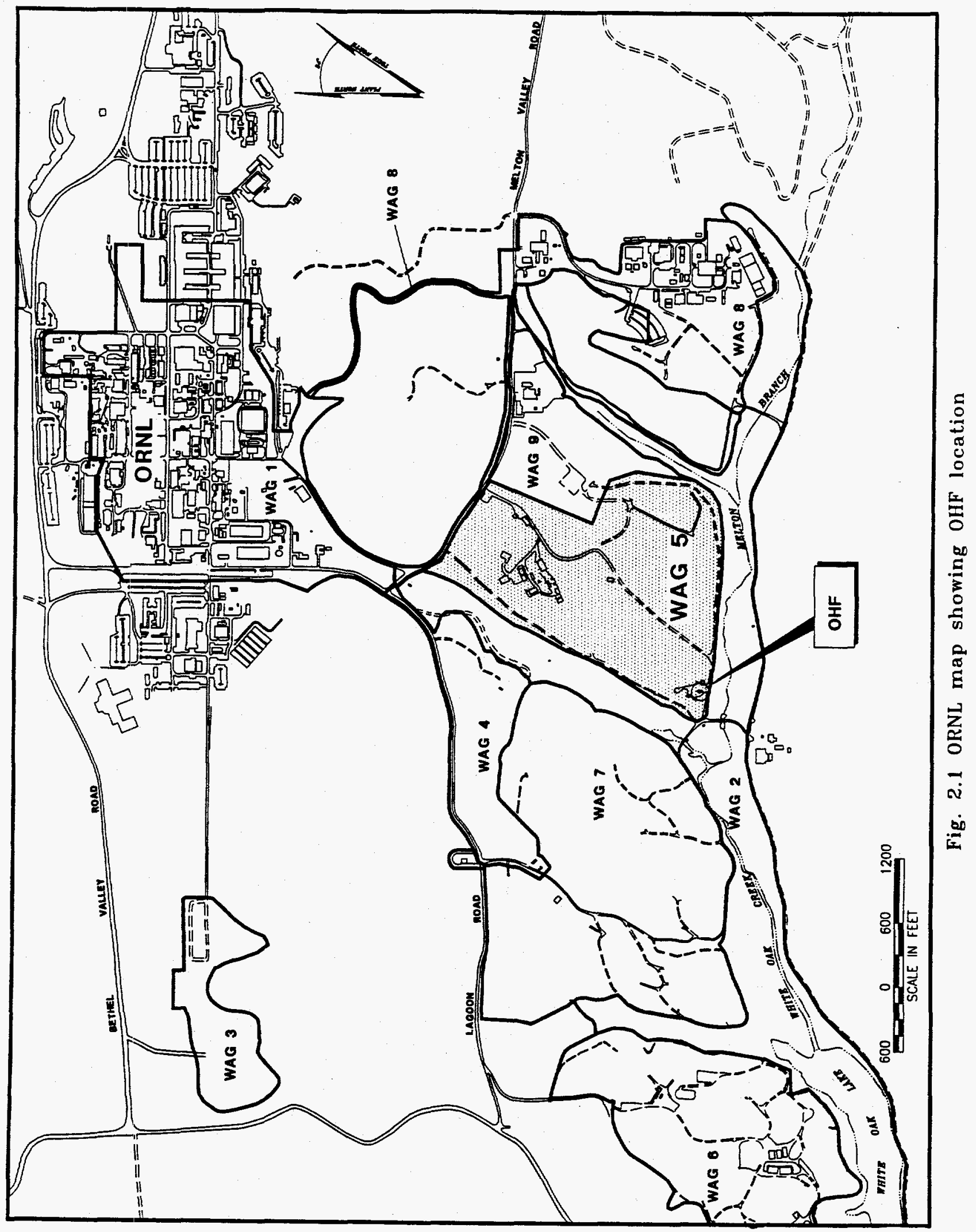




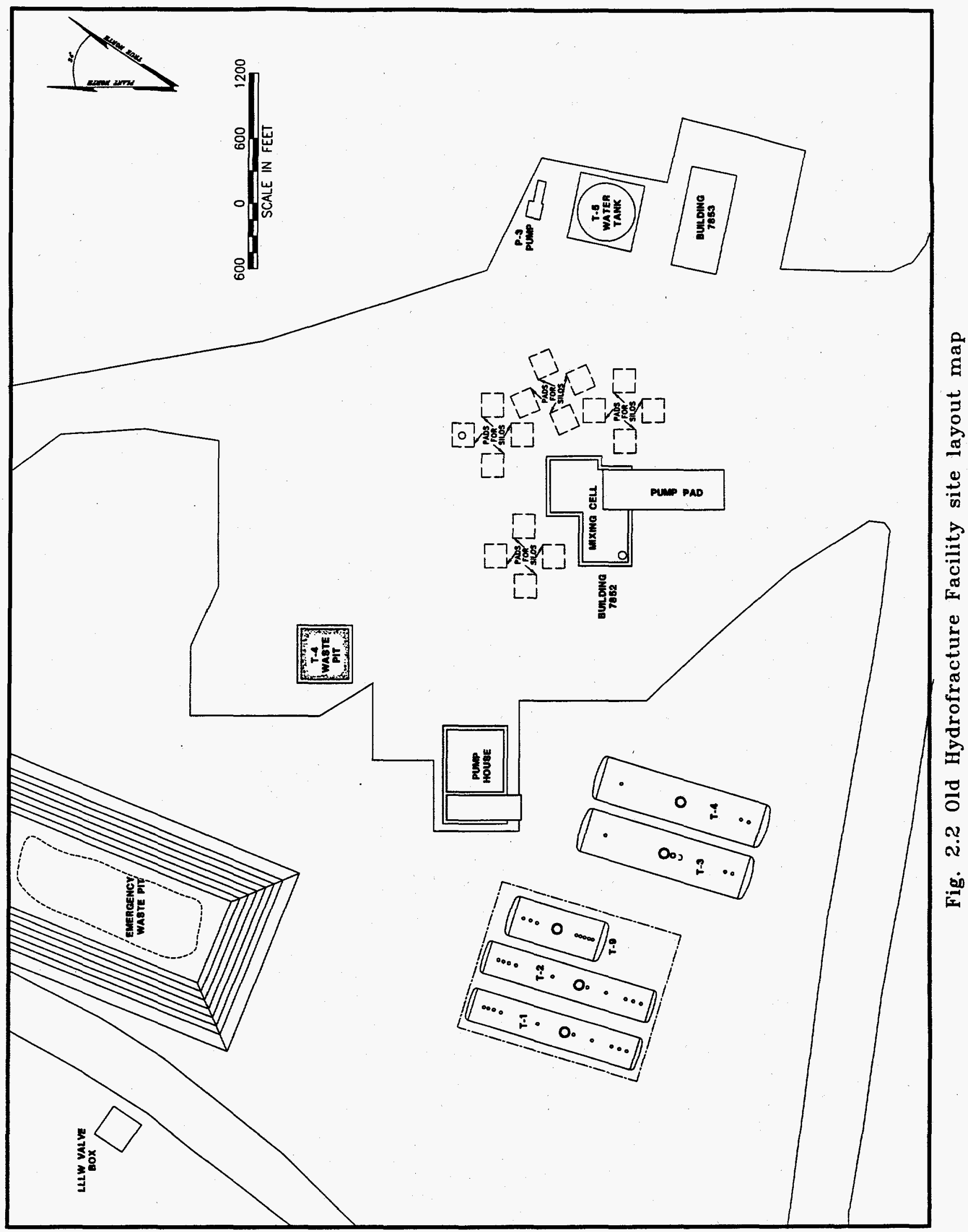


Figure 2.3 provides a plan view of the five tanks. ${ }^{\perp}$ Tanks T-3 and T-4 are buried together in a second pit. A 4-in. perforated vitreous clay pipe laid between the two tanks drains the pit into a 12-in. dry well. A 4-in. outlet pipe exits the well approximately $2 \mathrm{ft}$ above the bottom of the excavation. Anecdotal information suggests that this pipe is connected to the outlet for Tank T-9, upslope of the concrete box that encloses the end of the pipe. However, drawings confirming this piping arrangement have not been located. The concrete box designated "Box A" in the figure contains the outlet pipes for $T-1$ and $T-2$. The box designated "Box B" contains the pipe into which the T-9 and possibly the T-3/T-4 outlets are connected.

Following installation of the tanks, each excavation pit was filled with between 5 and $6 \mathrm{ft}$ of 1-in. gravel (tanks T-1, T-2, and T-9 pit) or crushed stone (tanks T-3 and T-4 pit). A 6-mil polyethylene plastic sheet was placed atop the gravel or stone and a minimum of $4 \mathrm{ft}$ of fill dirt was used to bring each pit to the finished grade. Figure 2.4 shows a vertical section of the backfilled tank pits.

Pre-construction drawings for the facility show the drainage pipes lying several inches above the bottom of the excavations ( 7 -in. in the T-1/T-2/T-9 excavation and 4 -in. in the T-3/T-4 excavation). Based on this design, a substantial volume of liquid could collect in the bottom of the tank pits before flowing through the perforated pipes into the dry wells where it would be detected. No as-built drawings have been located to confirm this construction. Figures 2.5 and 2.6 present details of the tank drainage systems, highlighting the elevations of the drainage pipes and well outlet pipes. ${ }^{2}$

Assuming the drainage pipes are placed as indicated in the pre-construction drawings, one can calculate the potential "holding capacity" of each cell - the amount of liquid that could potentially accumulate in the bottom of the excavation and not flow into the dry well. Estimated maximum liquid holding capacities for the OHF tank drainage beds are shown in Table 2.2. ${ }^{3}$

Table 2.2. Estimated maximum holding capacities of tank drainage beds

\begin{tabular}{cc}
\hline Cell & $\begin{array}{c}\text { Estimated holding capacity below drainage pipes } \\
\text { (gal) }\end{array}$ \\
\hline T-1 & 1,140 \\
T-2 & 930 \\
$T-9$ & 1,350 \\
T-3/T-4 & 1,290 \\
\hline
\end{tabular}

'The figures presented in this section are based on engineering drawings E-004-D (1963) and EE-042-D (1966), prepared before construction. No as-built drawings verifying the dry well system layout have been located.

${ }^{2}$ These figures are based on engineering drawings E-004-D (1963) and EE-042-D (1966), prepared before construction. No as-built drawings verifying the dry well system layout have been located.

${ }^{3}$ Appendix A includes calculations for the estimated holding capacities of the tank excavations. 


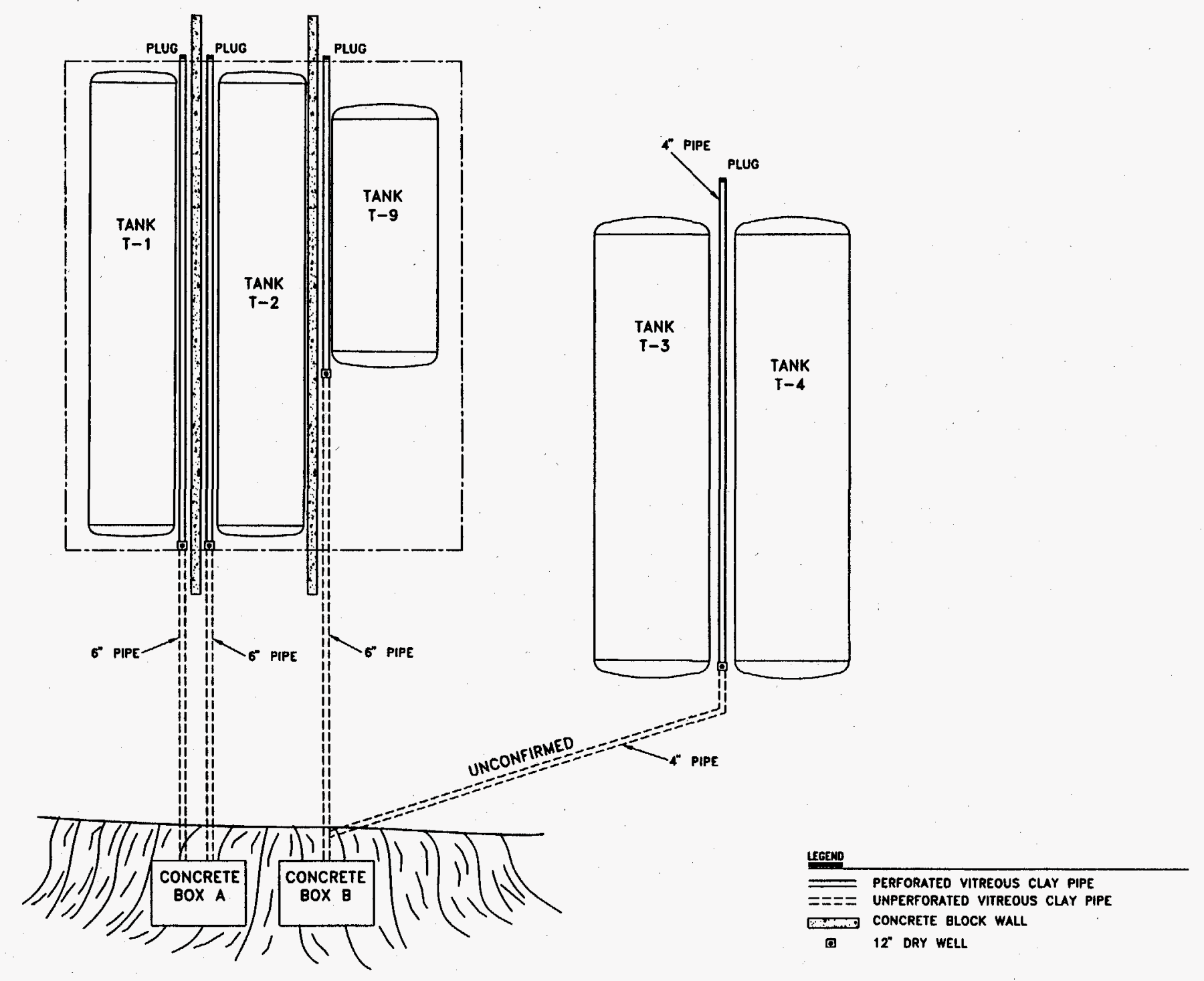

Fig. 2.3 OHF tanks dry well system - plan view 


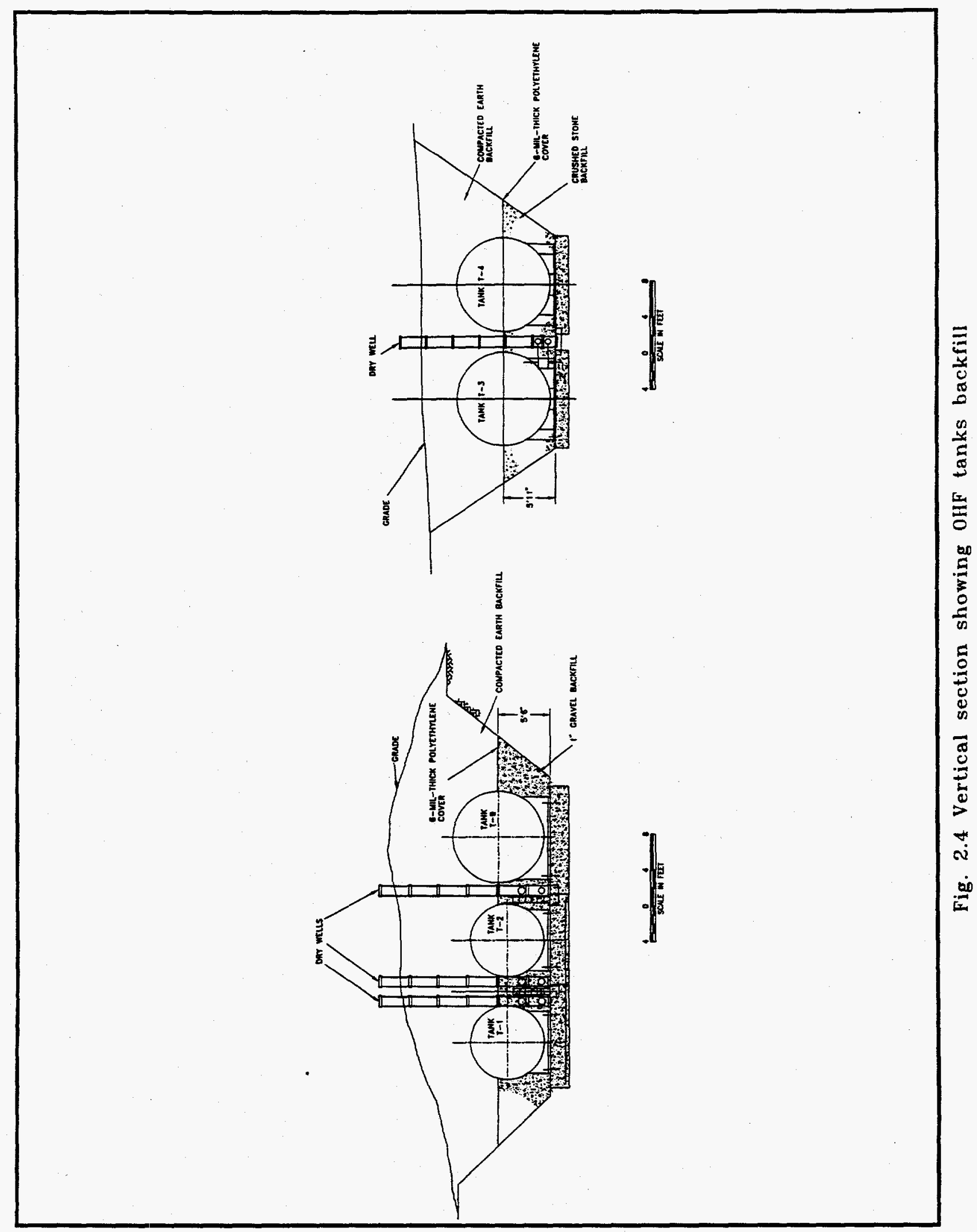




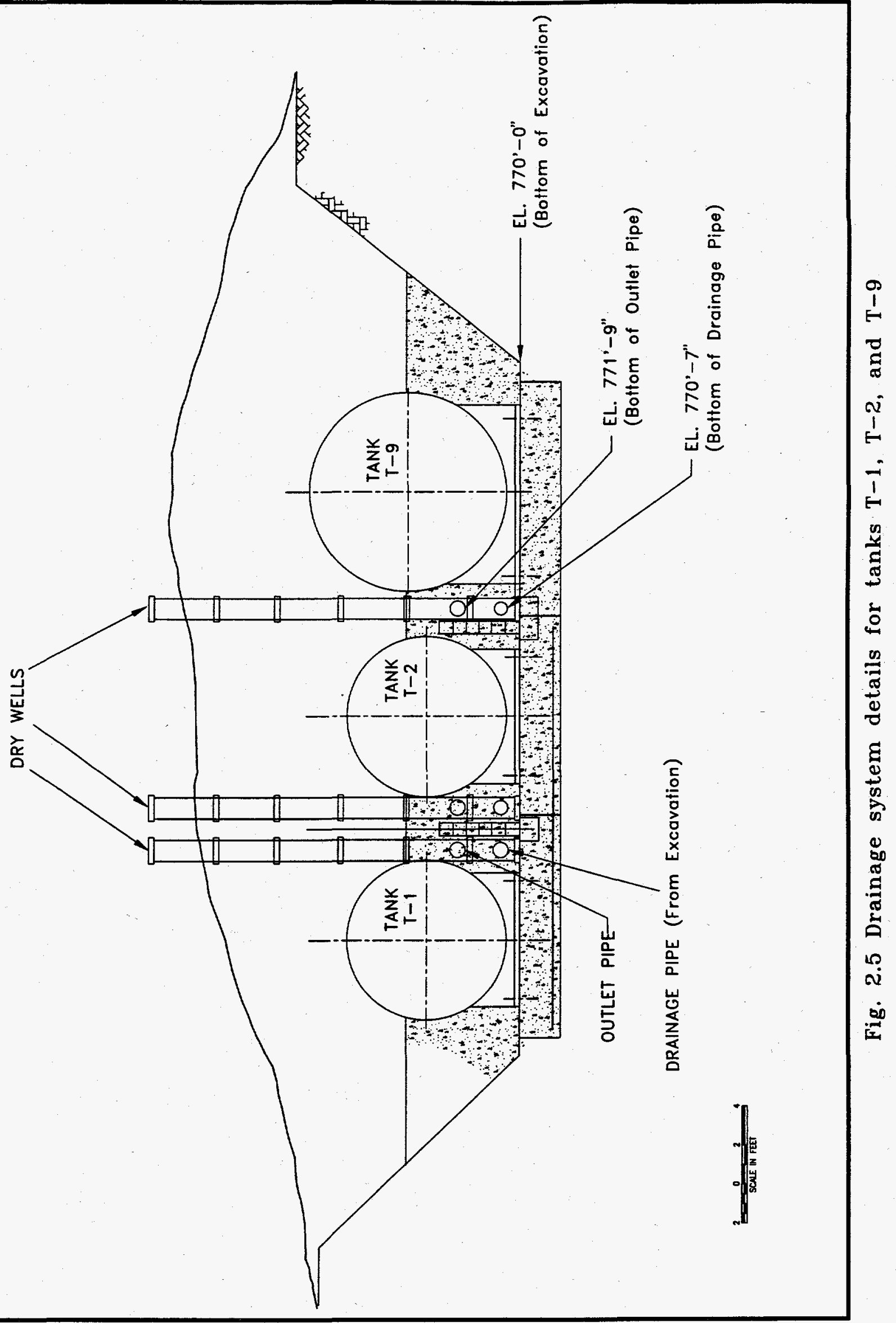




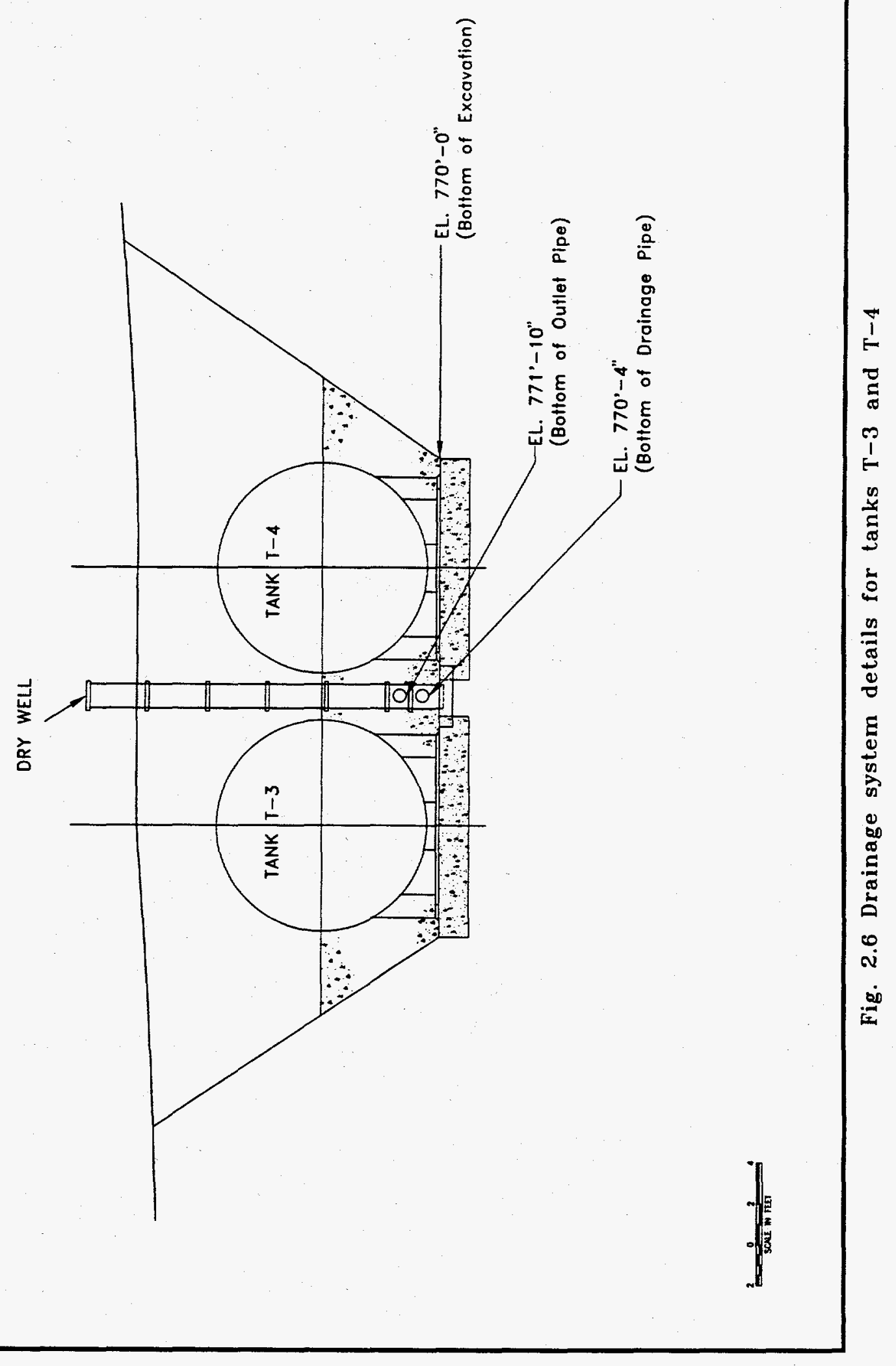




\subsection{SURFACE WATER HYDROLOGY}

The OHF is located on a surface drainage divide separating the White Oak Creek Basin and the Melton Branch Basin. As shown in Fig. 2.7, surface water runoff from the ground surface above the tanks flows into both White Oak Creek and Melton Branch, the primary tributary to White Oak Creek. From White Oak Creek, surface water flows into White Oak Lake and ultimately the Clinch River.

As described in Sect. 2.1, the outlet pipes from the tank dry wells exit the ground just north of the facility access road, approximately $230 \mathrm{ft}$ from Melton Branch. Any liquid collecting in the tank drainage beds above the elevation of the outlet pipes (approximately $2 \mathrm{ft}$ above the bottom of the excavations), would be expected to flow through the outlet pipes, into the drainage ditch beside the access road, and toward both Melton Branch and White Oak Creek. Any liquid collecting in the excavations below the level of the outlet pipes, would be expected to discharge to the groundwater, as described in Sect. 2.3.

\subsection{GROUNDWATER HYDROLOGY}

The Conceptual Site Model for Risk Assessment for the OHF Tanks (Energy Systems 1996b) describes the subsurface hydraulic setting for the tanks. As described in that document and as illustrated in Fig. 2.8, the OHF tanks are located in the unsaturated zone, 5-6 ft above the water table. Liquids discharged from the tank drainage beds to the subsurface would be transported either horizontally through the shallow subsurface to Melton Branch, or vertically to the saturated zone. Groundwater flow at the OHF is southeast toward Melton Branch. In evaluating the contaminant flow through the saturated zone, the conceptual model assumes a hydraulic gradient of 0.01 and a hydraulic conductivity of $5.0 \times 10^{-5} \mathrm{~cm} / \mathrm{second}$. 


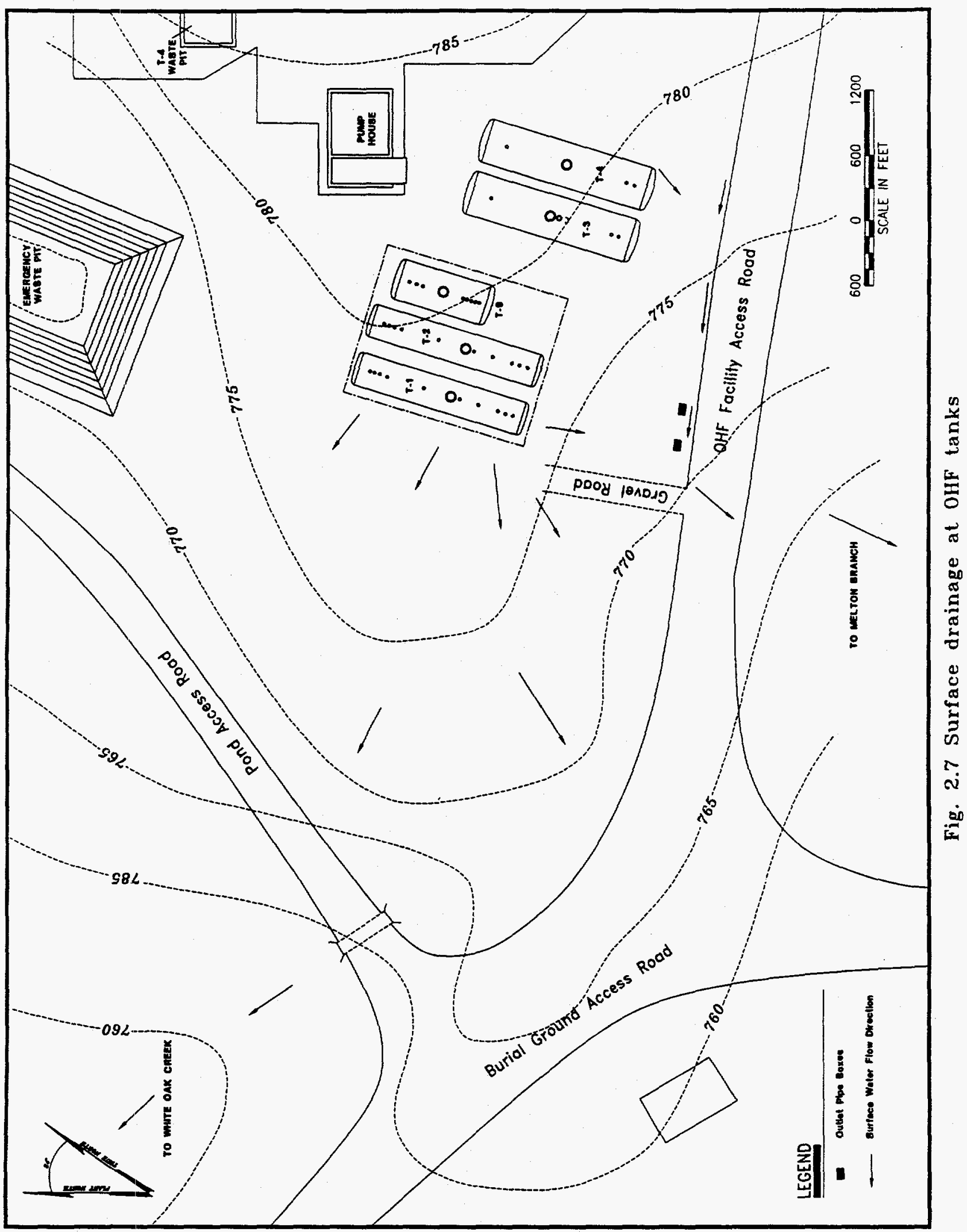



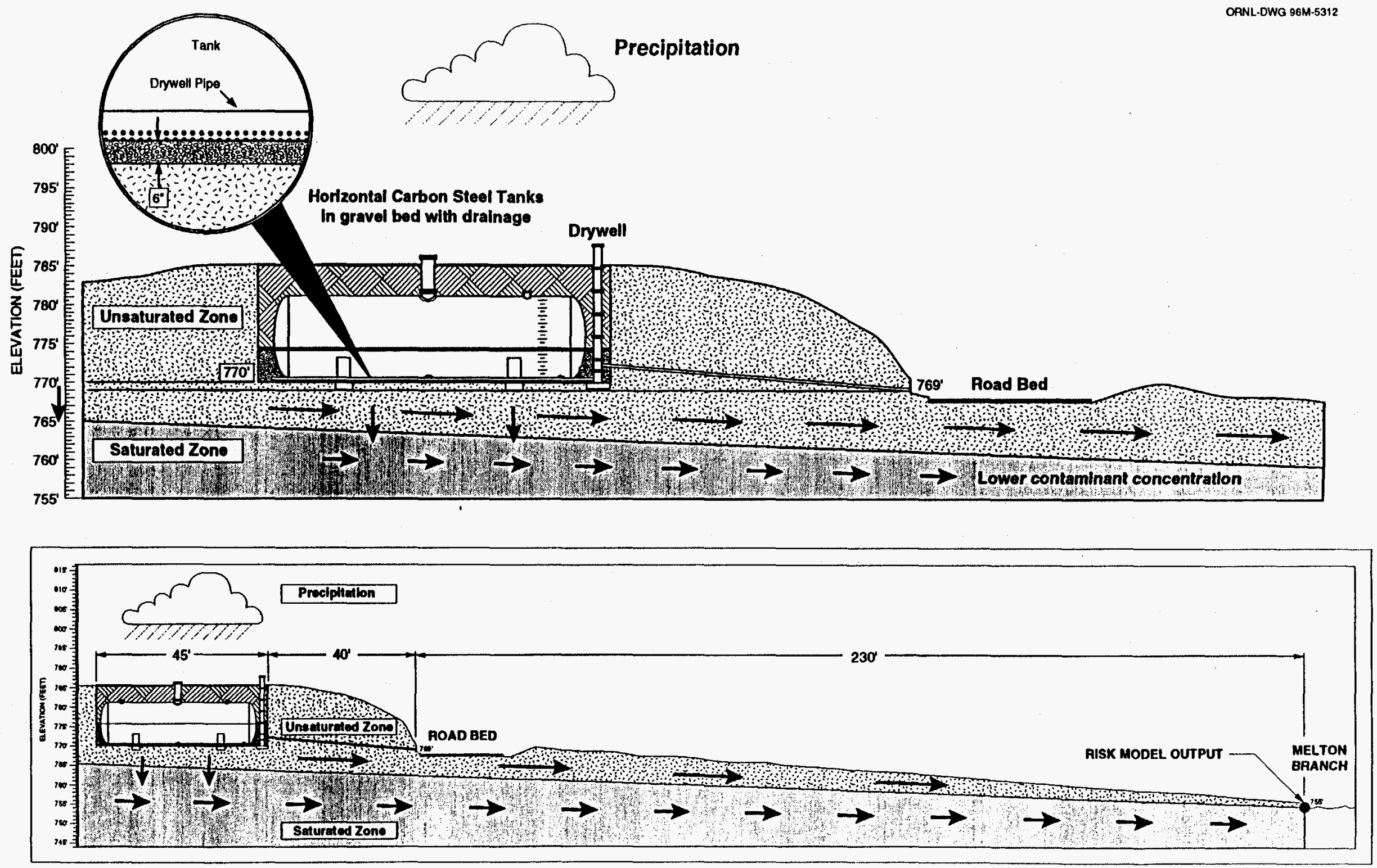

Fig. 2.8 Groundwater flow at oHF tanks 


\section{PLANNED SLUICING OPERATION}

The preliminary design of the planned sluicing operation is discussed in detail in the Preliminary Engineering Report, Old Hydrofracture Facility Tanks Content Removal Project (Energy Systems 1996c), and described only briefly here. Field activities for the project consist of three stages of operations: (1) construction and setup of the necessary equipment, instrumentation, and piping; (2) sluicing and transfer of the tank contents to the MVST; and (3) dismantling and decontamination of equipment and piping.

\subsection{CONSTRUCTION AND SETUP}

A few modifications to the tanks are required to prepare for sluicing. Two new risers (standpipes) have been installed in each tank, one at each end, close to the end welds. A new suction leg will be installed in tanks $\mathrm{T}-1, \mathrm{~T}-2, \mathrm{~T}-3$, and $\mathrm{T}-4$, and a mechanical mixer will be installed in tank T-9.

A new temporary pipeline will be installed to pump the tank contents to a valve box located approximately $50 \mathrm{ft}$ west and $285 \mathrm{ft}$ north of the OHF pump/valve vault's northwest corner, where it will enter an existing pipeline that connects the active ORNL LLLW evaporator tanks to the MVST (Fig. 3.1). The valve box will need to be modified to accommodate the new pipeline.

Several additional site modifications will be required, including power line relocation and tiein, setup of equipment trailers, and installation of a new flange on the existing ventilation system. Before sluicing each tank, the portable sluice equipment will be put in place and temporary shielding installed.

\subsection{TANK SLUICING AND WASTE TRANSFER}

The contents of tanks T-1, T-2, T-3, and T- 4 will be removed by resuspending the sludge in process water or supernatant (if approved by the ORNL Nuclear Criticality Safety Section), referred to as "sluice water," and pumping it to the MVST. Resuspension of the sludge will be accomplished by spraying process water or supernatant into the tank, referred to as the "sluice tank," pumping it out to a recycle tank (tank T-9), and recirculating it through the sluice and recycle tanks by spraying and pumping. When the solids content of the supernatant reaches a predetermined level, recirculation will be halted and the sluice water will be pumped to the MVST. At that point, one "sluice pass" will have been completed. Successive sluice passes will proceed until the sludge removal goal is achieved. The tanks will be cleaned one at a time. A process flow diagram, reprinted from the Preliminary Engineering Report, Old Hydrofracture Facility Tanks Content Removal Project (Energy Systems 1996c), is presented as Fig. 3.2.

The tanks will be sluiced using a modified, commercially available tank cleaning system, which is portable and will be moved from tank to tank. The basic components include a sprayer nozzle, pumping system with doubly contained piping, ventilation system, instrumentation for remote operation, and a video camera and light source. 


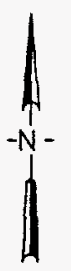

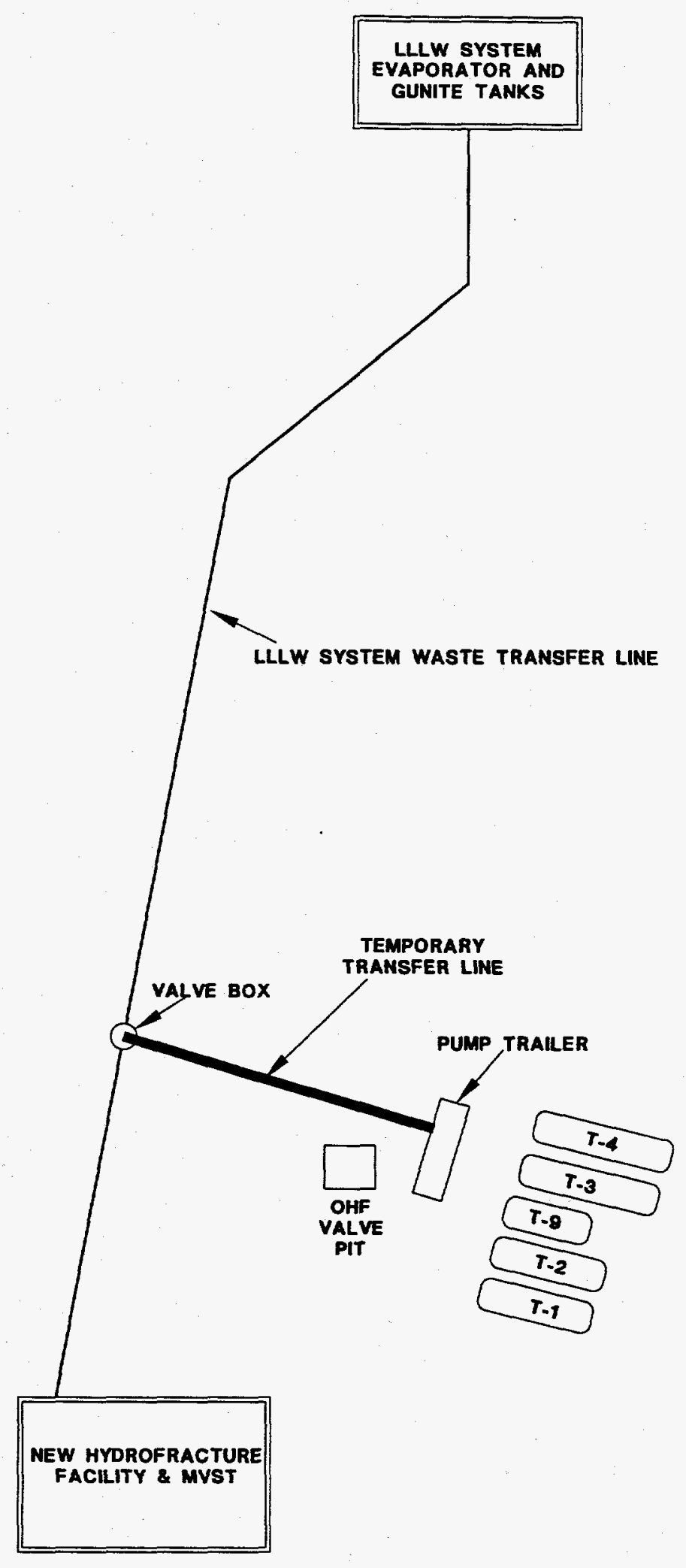

Fig. 3.1. Temporary waste transfer line location 

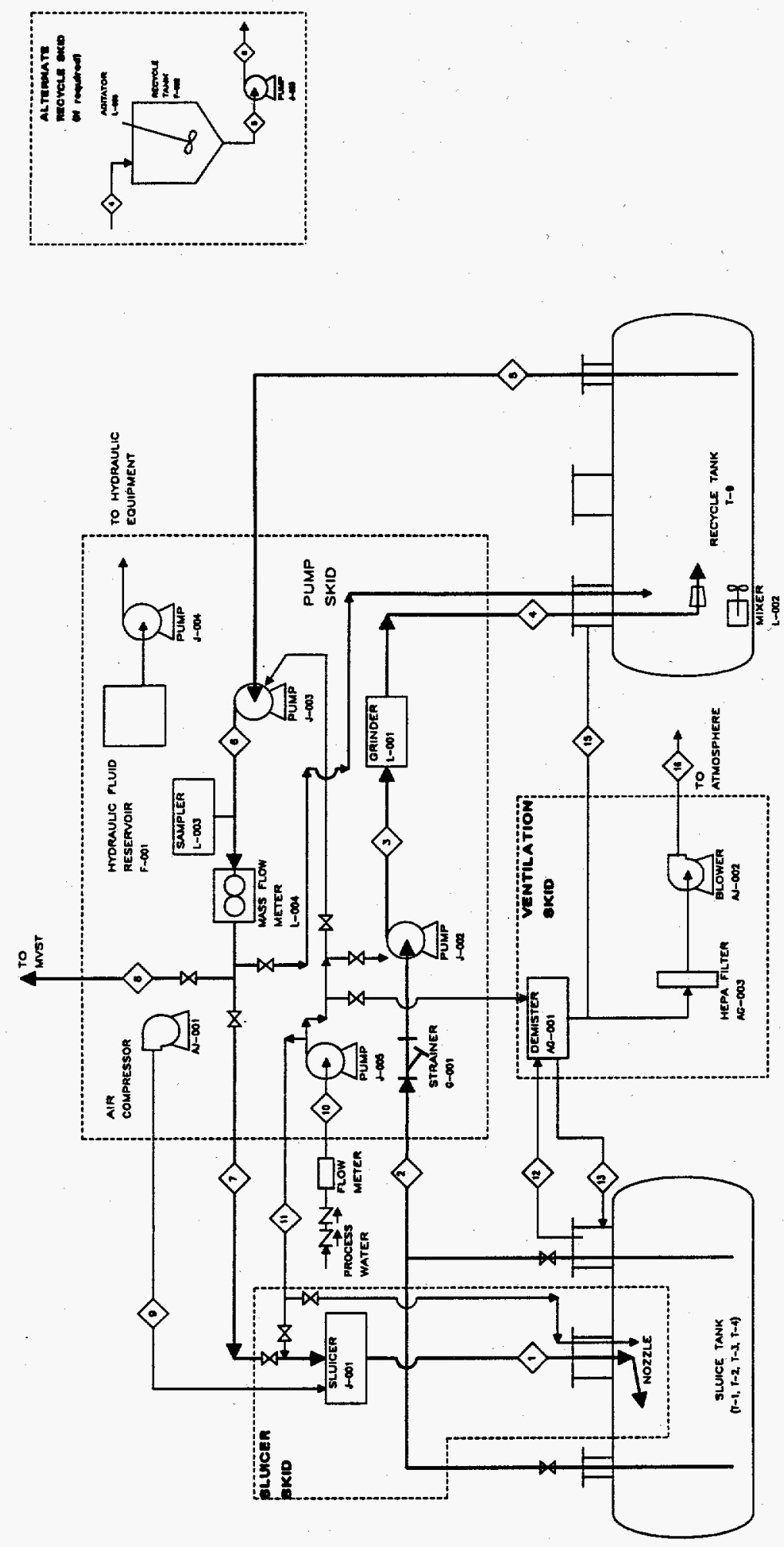
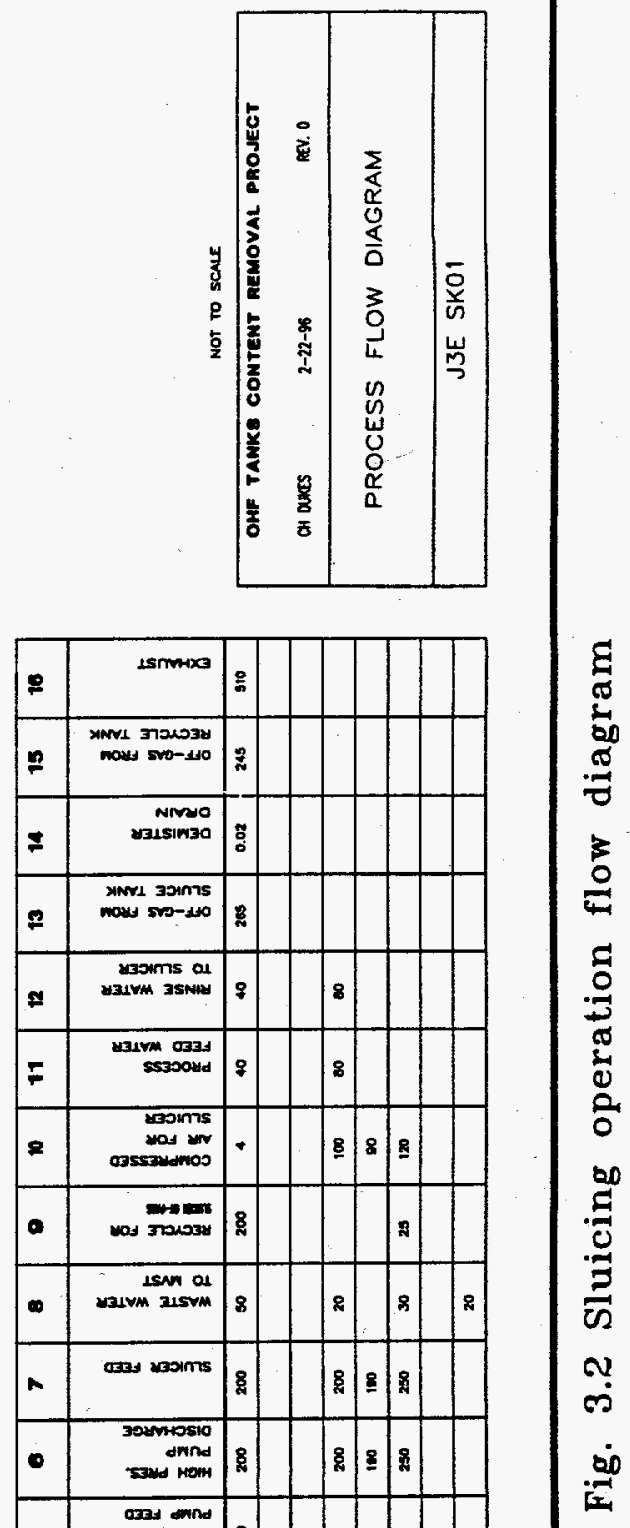


\subsection{EQUIPMENT DISMANTLING AND DECONTAMINATION}

The temporary pipeline used to transfer the tank contents to the MVST valve box will most likely be declared waste at the end of the project. If declared waste, the pipeline will be flushed with process water, cut up, and stored or disposed in accordance with applicable ORNL waste management procedures. Other equipment will be decontaminated and made available for reuse or left in place awaiting final remediation of the site. 


\section{ACCIDENT/RELEASE SCENARIOS}

This contingency plan evaluates a series of possible accident/release scenarios that have been identified for the OHF tank sluicing project. Eight scenarios are identified in Sect. 4.1. Sections 4.2 through 4.5 discuss each of the scenarios, including the possible causes, likelihood of occurrence, release mechanisms, exposure pathways, and release potential.

\subsection{OVERVIEW OF ACCIDENT/RELEASE SCENARIOS}

Eight basic accident/release scenarios have been identified for the OHF tank sluicing project, as follows:

1. nuclear criticality,

2. tank rupture,

3. tank leak,

4. tank overflow,

5. waste transfer pipeline rupture or leak,

6. leak from operating sluice equipment,

7. spill from sluice equipment during maintenance or disconnection, and

8. ventilation system failure.

Table 4.1 lists each of the accident/release scenarios, along with the possible causes, likelihood of occurrence, indicators of event occurrence, potential exposure pathways, and potential release volumes.

\subsection{NUCLEAR CRITICALITY}

Criticality is included as an accident scenario, despite the improbability of occurrence, because the results of the 1995 sampling project showed ratios of fissile material in the tanks that triggered the need for a Nuclear Criticality Safety Approval (NCSA). NCSA 39, "Fissionable Material Storage and Operations in OHF Tanks," May 29, 1996, covers the current storage mode of operation at the OHF and may be amended before sluicing begins. However, several requirements of NCSA 39 will likely be retained. They are described in Sects. 5.1.1 and 5.2.1.

\subsection{UNDERGROUND RELEASE}

Two types of underground liquid release were identified as possible accident/release situations that could occur during the tank sluicing and pumping project-tank rupture, which could result in total or near total release of tank contents, and tank leak, which could result in partial release of tank contents. As shown in Table 4.1, the underground release scenario poses the risk for the largest release, 14,700 gal. The Conceptual Site Model for Risk Assessment for the OHF Tanks (Energy Systems 1996b) estimated the risk posed by leakage of the contents of all five tanks to be less than $1 \times 10^{-4}$ at the Melton Branch seep face, if leakage is mitigated as described in Sect. 5. 
Table 4.1. Sluicing project accident/release scenario matrix

\begin{tabular}{|c|c|c|c|c|c|}
\hline Accident/ release & Possible causes & $\begin{array}{l}\text { Likelihood of } \\
\text { occurrence }\end{array}$ & Indicator & $\begin{array}{c}\text { Potential exposure } \\
\text { pathway }\end{array}$ & $\begin{array}{l}\text { Release } \\
\text { potential }\end{array}$ \\
\hline 1. Nuclear criticality & $\begin{array}{l}\text { Unintentional concentration of } \\
\text { nuclear material }\end{array}$ & Improbable & $\begin{array}{l}\text { Alarming high-range } \\
\text { dosimeter }\end{array}$ & $\begin{array}{l}\text { Personnel exposure } \\
\text { Air dispersion } \\
\end{array}$ & ND \\
\hline \multirow[t]{5}{*}{ 2. Tank rupture } & Earthquake & Improbable & \multirow{5}{*}{$\begin{array}{l}\text { Video observation } \\
\text { Liquid in dry well (high } \\
\text { level alarm) } \\
\text { T-9 continuous level } \\
\text { monitor }\end{array}$} & \multirow{5}{*}{$\begin{array}{l}\text { Subsurface } \\
\text { contamination }\end{array}$} & \multirow{5}{*}{$\begin{array}{c}8,384-42,150 \\
\mathrm{gal}^{h}\end{array}$} \\
\hline & Earth pressure load & Extremely low & & & \\
\hline & Heavy equipment load & Low & & & \\
\hline & Sluicer installation and shift & Low & & & \\
\hline & Sluice jet & Extremely low & & & \\
\hline 3. Tank leak & Current undetected leak & Low & $\begin{array}{l}\text { Video observation } \\
\text { Liquid in dry well (high } \\
\text { level alarm) } \\
\text { T-9 continuous level } \\
\text { monitor }\end{array}$ & $\begin{array}{l}\text { Subsurface } \\
\text { contamination }\end{array}$ & $8,384 \mathrm{gal}^{\mathrm{c}}$ \\
\hline 4. Tank overflow & $\begin{array}{l}\text { Overfilling (power failure, operator } \\
\text { error) }\end{array}$ & Low & $\begin{array}{l}\text { High level alarm } \\
\text { T-9 continuous level } \\
\text { monitor }\end{array}$ & $\begin{array}{l}\text { Surface contamination } \\
\text { Air dispersion }\end{array}$ & $8,384 \mathrm{gal}^{\mathrm{c}}$ \\
\hline \multirow[t]{2}{*}{$\begin{array}{l}\text { 5. Waste transfer pipeline rupture or } \\
\text { leak }\end{array}$} & $\begin{array}{l}\text { Improper equipment setup or } \\
\text { equipment flaw }\end{array}$ & Low & \multirow[t]{2}{*}{$\begin{array}{l}\text { Liquid in valve box sump } \\
\text { Visual observation }\end{array}$} & \multirow[t]{2}{*}{$\begin{array}{l}\text { Surface contamination } \\
\text { Air dispersion }\end{array}$} & \multirow[t]{2}{*}{$8,384 \mathrm{gal}^{c}$} \\
\hline & Vehicle accident & Low & & & \\
\hline \multirow[t]{2}{*}{$\begin{array}{l}\text { 6. Leak from operating sluice } \\
\text { equipment }\end{array}$} & Flange failure & Low & $\begin{array}{l}\text { Automatic pump cutoff } \\
\text { Visual observation }\end{array}$ & \multirow[t]{2}{*}{$\begin{array}{l}\text { Surface contamination } \\
\text { Air dispersion }\end{array}$} & \multirow[t]{2}{*}{$8,384 \mathrm{gal}^{\mathrm{c}}$} \\
\hline & Pump gasket failure & Low & $\begin{array}{l}\text { Liquid pooled in pump } \\
\text { trailer }\end{array}$ & & \\
\hline $\begin{array}{l}\text { 7. Spill from sluice equipment during } \\
\text { maintenance or disconnection }\end{array}$ & Spill & Low & Visual observation & $\begin{array}{l}\text { Surface contamination } \\
\text { Air dispersion }\end{array}$ & $65 \mathrm{gal}$ \\
\hline \multirow[t]{2}{*}{ 8. Ventilation system failure } & Fan shutdown & Low & & \multirow[t]{2}{*}{ Air dispersion } & \multirow{2}{*}{$\begin{array}{c}2,605 \mathrm{ft}^{3} \\
\text { unfiltered air }\end{array}$} \\
\hline & HEPA filter failure & Low & Pressure increase & & \\
\hline
\end{tabular}

"Significant air dispersion only if failure of ventilation system.

"Expected contents of tank T-3 (highest radioactivity) at first sluice pass to current volume of all five tanks.

'Expected contents of tank T-3 (highest radioactivity) at first sluice pass.

ND - Not determined 


\subsubsection{Tank Rupture}

For purposes of this report, a tank rupture is a breach in the tank wall that causes total loss of the tank contents to the subsurface. Possible causes of a tank rupture include the pressure of the earth fill above the tank, an earthquake, the pressure of the sluice jet, and load increases due to any of the following: hoisting and securing the sluicer on each tank, shifting of the sluicer, and placement of heavy equipment on the ground surface above a tank.

As noted in Sect. 1.2, evaluations of the structural integrity of the tanks indicate that tank rupture is highly unlikely. Based on the measurements of tank coupons cut during installation of the new risers, the tanks appear to have retained sufficient wall thickness to support the loads projected to be imposed during the sluicing project. However, the significant release potential of the tanks warrants contingency planning for the rupture scenario.

The structural analyses performed on tank integrity did not evaluate the impact of an earthquake on tank integrity. The likelihood of an earthquake occurring during the sluicing project is considered to be improbable and the contingency strategy presented later in Sect. 5 does not plan for that scenario. Both the Preliminary Engineering Report, Old Hydrofracture Facility Tanks Content Removal Project (Energy Systems 1996c) and the Basis for Interim Operation, Facility 7852, Old Hydrofracture Facility (Energy Systems 1996a) discuss the earthquake potential and support the approach taken here.

Table 4.2 compares the current volumes of the tank contents to the volumes projected to be in each tank, or recirculating between the sluice tank and the recycle tank, during the first sluice pass. [See Appendix F, Preliminary Engineering Report, Old Hydrofracture Facility Tanks Content Removal Project (Energy Systems 1996c)]. Because this contingency plan covers only the sluicing project and not the current storage mode of operation, the release potential for each tank is the volume projected to be in the tank at the start of the first sluice pass.

Table 4.2 Current versus first sluice pass volumes of tank contents"

\begin{tabular}{ccc}
\hline Tank(s) & $\begin{array}{c}\text { Current volume } \\
\text { (gal) }\end{array}$ & $\begin{array}{c}\text { First sluice pass volume } \\
\text { (gal) }\end{array}$ \\
\hline T-1 & 8,450 & 3,304 \\
T-2 & 10,700 & 4,997 \\
T-3 & 5,150 & 8,384 \\
T-4 & 3,150 & 5,493 \\
T-9 & 14,700 & 2,024 \\
All & 42,150 & N/A \\
\hline
\end{tabular}

a Information presented in Appendix F, Preliminary Engineering Report, Old Hydrofracture Facility Tanks Content Removal Project (Energy Systems 1996c).

\subsubsection{Tank Leak}

A localized breach of a tank wall is considered a tank leak for purposes of this document, as opposed to a tank rupture, which is considered total failure of the tank wall as a containment 
system. The possible cause of a tank leak, as noted in Table 4.1, is leaking through currently undetected breaches in the tank walls. If breaches in the tank walls exist but are plugged with precipitated material, the plugs may dissolve during sluicing and begin leaking.

Because none of the tanks are known to be leaking at this time, this document only addresses the risk of leakage during the sluicing operation on each tank, and assumes that a maximum of two tanks would leak simultaneously-the tank undergoing sluicing (sluice tank) and the recycle tank, T-9. The worst-case leak scenario is the release of the contents of tank T-3 $(8,384$ gal) during the first sluice pass.

\subsection{ABOVEGROUND LIQUID RELEASE}

Several of the accident/release scenarios pose the risk of a release of liquid to the ground surface. These scenarios include tank overflow, waste transfer pipeline rupture or leak, operating sluice equipment leak, and spill from the sluice equipment during maintenance or during transfer between tanks. Each scenario is discussed briefly below.

\subsubsection{Tank Overflow}

A tank overflow might occur as the result of accidental overfilling with supernatant or process water. Overfilling might be a result of operator error or might occur during a power failure when the ability of control personnel to monitor tank influx is impaired. The potential for release shown in Table 4.1 is the entire contents of tank T-3, which exhibits the highest levels of radioactivity.

\subsubsection{Waste Transfer Pipeline Rupture or Leak}

The sluiced tank contents will be transported to the MVST via a new temporary pipeline running approximately $140 \mathrm{ft}$ from the sluice project pump trailer to an existing valve box, and then through a segment of existing pipeline that runs between the active LLLW system evaporator tanks and the MVST. This contingency plan addresses the possibility of a leak in the new temporary pipeline, which will be installed at the start of the project, but does not cover the possibility of a leak in the active pipeline. The active line is used routinely to transport waste to the MVST.

Possible causes of a leak in the transfer line include a defect in or improper installation of the equipment, or a vehicular accident.

The new temporary pipeline will consist of 2-in.-diameter, schedule 40 A-106 seamless pipe that will be contained in a 4-in.-diameter, clear polyvinyl chloride, helical reinforced hose. It will be installed aboveground. The low point of the line will be just inside the valve box. As noted in Table 4.1, the estimated release potential is $8,384 \mathrm{gal}$, which is the largest volume projected to be transferred at one time from tank $\mathrm{T}-3$, which exhibits the highest levels of radioactivity [see Appendix F, Preliminary Engineering Report, Old Hydrofracture Facility Tanks Content Removal Project (Energy Systems 1996c)]. This scenario assumes a catastrophic pipe rupture. 


\subsubsection{Leak from Operating Sluice Equipment}

Figure 3.2 presented the process flow diagram for the sluice and pump project, reproduced from the Preliminary Engineering Report, Old Hydrofracture Facility Tanks Content Removal Project (Energy Systems 1996c). As shown in the figure, sluice water will be sprayed through the sluicer nozzle into the sluice tank. From the sluice tank, the sluice water will be suctioned through a low pressure pump (with associated strainer and grinder) and discharged under low pressure (25-30 psig) to the recycle tank (T-9). From the recycle tank, it will be suctioned through a high pressure pump and discharged under high pressure (200 psig) to the sluicer, from which it is sprayed back into the sluice tank. A sampler and mass flow meter are included in the discharge line of the high pressure pump. Sluice water will be cycled through the sluice and recycle tank until the sludge in the sluice tank is resuspended to a level that will be specified for the project, at which point it will be transferred to the MVST. The pumps, strainer, grinder, sampler, and mass flow meter, along with assorted additional equipment, will be installed on a trailer referred to as the pump skid.

A leak in the sluice system would most likely result from failure of one of the several flanges connecting the various pieces of equipment, although a leak could theoretically occur anywhere in the system.

The impact of a leak in the sluice system depends on whether the leak occurs in a suction line or a discharge line. A leak in a suction line would likely drip, whereas a leak in a discharge line would likely spray. The release potential for this scenario is 8,384 gal (Table 4.1), which assumes catastrophic rupture of the lines, non-detection, and loss of the entire contents of tank T-3.

\subsubsection{Spill from Sluice Equipment During Maintenance or Transfer Between Tanks}

The sluice system used for the OHF tanks will be a portable system that will be used to sluice one tank at a time. Upon completion of sluicing at one tank, the sluice equipment will be disconnected manually by operating personnel and reconnected to the next tank. In addition, maintenance may be performed on the system during the course of the sluicing project. While procedures will be developed for flushing and draining the lines, there is a possibility of spilling tank contents while transferring the equipment. The release potential for this scenario is approximately 65 gal, which assumes the entire capacity of the portable pipelines is spilled.

\subsection{VENTILATION SYSTEM FAILURE}

During sluicing operations at the OHF tanks, the tanks will be ventilated and off gases treated with a high-efficiency particulate air (HEPA) filter before atmospheric discharge. Two types of failure in this system could result in unfiltered air from the tanks being discharged to the atmosphere.

During certain valve alignments, a shutdown of the ventilation system fan would result in a direct discharge of off gases to the atmosphere. Likely causes of fan shutdown include inadvertent shutdown, power failure, and breakage of the fan belt. 
A failure of the of HEPA filter would result in reduced filter performance and possibly the discharge of contaminants to the atmosphere. Filter failure could result from excessive moisture loading or a filter puncture. Excessive moisture loading would be characterized by an increase in the differential pressure across the filter. Filter puncture is only detectable by dioctyl phthalate (DOP) test and would not be evident during the sluicing operation.

Table 4.1 indicates a release potential of $2,605 \mathrm{ft}^{3}$ of unfiltered air. This assumes that ventilation system failure occurs in combination with tank overflow and that a volume of unfiltered air equal to the volume of void space in the least filled tank (T-4) ${ }^{+}$would be released through open ports.

+ Assuring expected tank T-4 volume of 5,493 gal at start of sluice pass (Energy Systems 1996c) compared to 25,000 gal capacity. 


\section{CONTINGENCY STRATEGY}

A two-part contingency strategy, including elements of prevention/detection and mitigation, is planned for the OHF tank sluicing and pumping project. The prevention/detection element is designed to minimize the risk of occurrence of an accident or release and ensure that an accident or release is detected in a timely manner. The mitigation element describes actions that will be taken to minimize the impact of any release or accident.

\subsection{PREVENTION/DETECTION}

This section describes measures that will be taken to minimize the risk of occurrence of the accident/release scenarios discussed in Sect. 4 of this report and to ensure that any accident/release is detected as quickly as possible. Preventive measures include design features of the sluicing and pumping equipment, as well as operating procedures designed for the project. Detection methods range from visual inspection to electronic sensors and alarm systems.

\subsubsection{Nuclear Criticality Prevention/Detection}

To meet ORNL waste acceptance criteria, the fissionable material in the OHF tanks may need to be denatured by adding ${ }^{238} \mathrm{U}$ before sluicing. Additional measures taken to prevent criticality are prescribed by NCSA 39 (1996), which may be modified before sluicing begins, and are listed below:

- No additions of fissionable material will be made to any OHF tank.

- Transfers of LLLW between OHF tanks will be made only after notifying the Nuclear Criticality Safety Section and modifying the NCSA, except that in emergency situations (e.g., tank leak) LLLW may be transferred from $T-1, T-2, T-3$, or $T-4$ to $T-9$ and LLLW may be transferred from $T-9$ to any other tank except T-3.

- Liquid will be maintained at or above the sludge level in each OHF tank.

The status of the OHF tanks with regard to criticality concerns will be monitored. Project personnel will report to the Nuclear Criticality Safety Section immediately any analytical measurement that shows certain chemical and physical characteristics of the tank contents, as specified in Condition of Approval 2 of the NCSA.

Persons working near a tank port or over the tank will wear an alarming high-range dosimeter, or use alternative, equivalent equipment.

\subsubsection{Underground Release Prevention/Detection}

While the causes of tank rupture and tank leak vary, the release mechanisms are similar; tank contents are released to the subsurface drainage bed that surrounds the buried tanks. 
Methods of preventing tank leaks and ruptures focus on evaluating the condition of the tanks before the start of the project to affirm the competence of the tanks to withstand the anticipated stresses. As discussed in Sect. 1, structural analyses have affirmed the integrity of the tanks. In addition, the placement of heavy equipment on the ground surface above the tanks may be prohibited. The perimeters of each tank would be roped off and signs posted to warn against heavy equipment placement.

A three-part monitoring program is proposed for detecting a tank leak or rupture. As noted in Sect. 4, it is assumed that the risk of a tank leak or rupture is likely only during sluicing, and that no more than two tanks at a time will be involved in sluicing (sluice tank and recycle tank). Each tank will be monitored for leaks/rupture during the time it is involved in sluicing.

The core of the leak/rupture monitoring program is an alarmed conductivity probe that will be installed in the dry well of the sluice tank, just above the surface of any liquid contained in the well, or on the bottom if the well is dry. The alarm will alert personnel in the control trailer of the problem. It is assumed that any liquid released from the tanks would flow through the drainage pipe into the dry well,,$^{5}$ and that an increase in the level of liquid in the well will be treated as a release from the tank.

A video monitor and level monitors in the tanks will supplement the well monitoring probe. While it is unlikely that a tank leak would be visible on the video monitor, a tank rupture should be noticeable, allowing immediate response. A continuous liquid level monitor will be operating in tank T-9 while it is used as a recycle tank during sluicing of tanks $T-1, T-2, T-3$, and $T-4$ and might signal a loss in the integrity of the T-9 wall before liquid is detected in the dry well. Turbulence during sluicing will prevent level monitor operation in the sluice tanks.

\subsubsection{Tank Overflow Prevention/Detection}

The risk of tank overflow exists while sluice water is being transferred from one tank to another before the start of sluicing, and during the addition of process water to a tank or to another point in the sluice cycle. Tank overflow is not expected to be an issue during sluicing, unless process water is flowing into the system, because the volumes of liquid in the tanks will probably be far below tank capacities at the start of sluicing.

The risk of tank overflows will be minimized by carefully monitoring flow between tanks, the flow of process water into the system, and water levels in the tanks. The process water valve will be isolated to prevent accidental opening during off-shift hours. In addition, alarmed highlevel indicators will be installed on each tank and a continuous level monitor installed on tank T-9 will be monitored from the control trailer. An increase in liquid level above that expected or, particularly, an alarm from the high-level indicators, should alert operators to a potential overflow situation before a spill occurs.

\footnotetext{
${ }^{3}$ As noted in Sect. 2, the drainage pipes may not be placed on the bottom of the excavation, in which case liquid released from a tank would flow into the dry well only after it rises to the elevation of the drainage pipe.
} 
Table 4.1 lists power failure as a potential cause of tank overfilling. While the preliminary engineering design calls for a fail-safe system, in which valves would fail shut, this system would probably not cover the process water valve, which would need to be shut manually. However, the final engineering design for the project may consider an uninterruptable power supply for control instrumentation, which would ensure continued function of the high-level indicators during a power failure.

\subsubsection{Waste Transfer Pipeline Leak Prevention/Detection}

The pipeline used to transfer the sluiced tank contents to the MVST valve box tie-in will be installed aboveground and will be a doubly contained system. It will consist of 2-in.-diameter, schedule 40 A-106 seamless pipe, contained within a 4-in.-diameter, clear polyvinyl chloride, helical reinforced hose. It will function as a gravity-flow system and the low-point will be just inside the valve box connection to the MVST pipeline. Any leaking liquid would be expected to flow downslope into the valve box and collect in the concrete sump. The sump is equipped with an alarmed conductivity probe, which, if triggered, alerts personnel at the Waste Operations Control Center. During the course of the sluicing project, they will be instructed to inform the OHF project control center if the alarm is triggered. The control trailer will be equipped with a cellular phone. In addition, the pipeline will be visually inspected by OHF project personnel daily for any indications of a leak.

\subsubsection{Sluice System Leak Prevention/Detection}

Several leak prevention features have been designed into the tank sluicing system. First, the discharge pipe segments, through which supernatant flows from the low pressure pump into the recycle tank, and from the recycle tank to the sluicer, will be doubly contained and equipped with pressure relief and pump cutoff systems. The pressure relief lines are designed to divert supernatant from the discharge (pressurized) lines to the suction lines if the pressure in the discharge lines increases above the set point of the rupture disks. The pump cutoff system will include high pressure cut-off switches attached to the primary (interior) pipes and low pressure cut-off switches attached to the nitrogen-filled annulus between the primary and secondary pipes. If a discharge line becomes overly pressurized or the secondary (outer) pipe is breached, the pump will shut down automatically. Additionally, operators will be able to continuously monitor pressure in the pumps and to control pump operation from the control trailer.

Second, the suction lines drawing supernatant from the sluice tank to the low pressure pump and from the recycle tank to the high pressure pump will be supported such that any leaking liquid would flow, via gravity, back into the tank. Plastic sheeting will be placed on the ground along the length of the suction lines to catch any drips.

Third, a 6-mil plastic film secured to hoop stanchions will be placed over the pump skid to contain any leaked or sprayed liquid in the event of a line or seal failure. The pump skid will house the two pumps, strainer, grinder, flow meter, and sampler; and the hydraulic motor and pump.

Another feature designed to prevent leaks from the sluicing system is the use of flange guards on all flanges connecting the various equipment through which the supernatant will flow. These guards will prevent spraying from flange connections in the event of seal rupture. 
Finally, because all of the sluicing equipment will be installed aboveground, leaks may be detected visually by project personnel.

During maintenance and during transfer from one tank to another, applicable operating procedures will be followed to prevent spills. Any spilled liquids should be visible to project personnel.

\subsubsection{Ventilation System Failure Prevention/Detection}

To minimize the risk of ventilation fan shutdown, fan belts will be inspected for tightness and wear before the beginning of sluicing each tank and the ventilation system will be operated by qualified personnel. In the event of a fan failure, sluicing will be stopped and the ventilation operator will align system valves to minimize atmospheric release.

In the event of an increase in the differential pressure across the HEPA filter, the sluicing operation will be stopped and the system inspected for excessive moisture loading. Appropriate actions to assure proper HEPA filter operation will be taken before restart of the sluicing operation.

\subsection{MITIGATION}

This section outlines actions that will be taken to mitigate an accident/release, should it occur. Table 5.1 presents a matrix that summarizes mitigative measures that should be taken when various indicators suggest possible releases.

\subsubsection{Nuclear Criticality Mitigation}

If an alarming dosimeter or alternative instrument provides indication of even a momentary high-dose rate (a pulse of radiation), all persons will immediately withdraw to the designated assembly area and treat the occurrence as a criticality emergency, until it is determined to be otherwise. The Laboratory Shift Superintendent will be notified immediately.

If any of the conditions of the specified preventive methods fail, the project personnel will take the following actions, as specified in NCSA 39, "Fissionable Material Storage and Operations in OHF Tanks," May 29, 1996, and the site-specific health and safety plan:

- cease operations;

- withdraw people at least $15 \mathrm{ft}$ from the OHF tanks;

- follow directions of the radiation-protection representative(s) in selecting an upwind assembly area in case of a criticality emergency;

- notify the Nuclear Criticality Safety Section; and

- follow documented advice given by the Nuclear Criticality Safety Section before proceeding with the tank activities. 


\section{$5-5$}

Table 5.1. Contingency matrix

\begin{tabular}{|c|c|c|}
\hline Indicator & Probable Cause & Mitigation \\
\hline \multirow[t]{2}{*}{ High-range dosimeter alarm } & \multirow[t]{2}{*}{$\begin{array}{l}\text { Assume criticality until } \\
\text { shown otherwise }\end{array}$} & $\begin{array}{l}\text { Withdraw personnel immediately } \\
\text { to designated assembly area }\end{array}$ \\
\hline & & $\begin{array}{l}\text { Notify Laboratory Shift } \\
\text { Superintendent immediately }\end{array}$ \\
\hline $\begin{array}{l}\text { Alarm indicates increase of } \\
\text { liquid in dry well }\end{array}$ & Tank rupture or leak & $\begin{array}{l}\text { Pump remaining tank and dry } \\
\text { well contents to recycle tank (if } \\
\text { recycle tank leak, pump to any } \\
\text { other tank except } T-3 \text { ) }\end{array}$ \\
\hline \multicolumn{3}{|l|}{$\begin{array}{l}\text { Video observation of unexpected } \\
\text { liquid level drop in sluice tank }\end{array}$} \\
\hline \multicolumn{3}{|l|}{$\begin{array}{l}\text { T-9 continuous level monitor } \\
\text { shows unexpected liquid level } \\
\text { drop }\end{array}$} \\
\hline \multirow{3}{*}{$\begin{array}{l}\text { Alarm indicates high level in } \\
\text { tank } \\
\text { T-9 continuous level monitor } \\
\text { indicates high liquid level }\end{array}$} & $\begin{array}{l}\text { Overfilling with process } \\
\text { water }\end{array}$ & $\begin{array}{l}\text { Shut process water valve, clean } \\
\text { up any spill }\end{array}$ \\
\hline & & \\
\hline & $\begin{array}{l}\text { Overfilling with } \\
\text { contents pumped from } \\
\text { another tank }\end{array}$ & Shut off pump, clean up any spill \\
\hline $\begin{array}{l}\text { Waste Operations Control Center } \\
\text { notifies OHF control center of } \\
\text { liquid alarm in MVST transfer } \\
\text { line valve box sump }\end{array}$ & \multirow[t]{2}{*}{$\begin{array}{l}\text { Leak from waste } \\
\text { transfer pipeline }\end{array}$} & \multirow[t]{2}{*}{$\begin{array}{l}\text { Shut valve to stop transfer of } \\
\text { liquid from T-9 to MVST, repair } \\
\text { line, clean up spill }\end{array}$} \\
\hline $\begin{array}{l}\text { Visual observation of liquid in } \\
\text { containment hose on waste } \\
\text { transfer line }\end{array}$ & & \\
\hline \multirow{3}{*}{$\begin{array}{l}\text { High- or low-pressure pump } \\
\text { shuts off automatically } \\
\text { Visual observation of liquid in } \\
\text { pump skid or below suction } \\
\text { hoses }\end{array}$} & \multirow{3}{*}{$\begin{array}{l}\text { Leak in sluicing } \\
\text { equipment (discharge } \\
\text { lines) } \\
\text { Leak in sluicing } \\
\text { equipment }\end{array}$} & \multirow[t]{3}{*}{$\begin{array}{l}\text { Stop sluicing, repair equipment, } \\
\text { clean up spill }\end{array}$} \\
\hline & & \\
\hline & & \\
\hline $\begin{array}{l}\text { Pressure increase in ventilation } \\
\text { system }\end{array}$ & HEPA filter failure & $\begin{array}{l}\text { Stop sluicing, align system } \\
\text { valves to minimize atmospheric } \\
\text { release, check system for excess } \\
\text { moisture loading, repair system }\end{array}$ \\
\hline Fan shutdown & Belt wear & $\begin{array}{l}\text { Stop sluicing, align system } \\
\text { valves to minimize atmospheric } \\
\text { release, repair system }\end{array}$ \\
\hline
\end{tabular}

Additional requirements will apply if NCSA 39 is modified for the sluicing project. 


\subsubsection{Underground Release Mitigation}

As noted in Sect. 4.2, a tank rupture or leak would be indicated by an unexpected loss of tank contents, as filmed by the in-tank video camera, or detected by the tank T- 9 continuous level indicator or the conductivity probe in a dry well. In the event of significant leak or rupture, the remaining tank contents will be pumped out of the breached tank as quickly as possible and as much liquid as possible will be pumped out of the drainage system well. Before initiating sluicing of a tank, operating personnel will make the necessary preparations to pump any liquid that collects in the associated drainage system dry well to the recycle tank.

The equipment needed to pump liquid from the dry wells includes a trash pump, a suction hose, discharge hose, and a foot valve. Before beginning sluicing, the pump discharge will be connected to the recycle tank, the pump intake will be placed in the well, and the pump will be primed. This will minimize the delay between release identification and pumping of the dry well. In addition, to ensure that tank contents do not flow from the well outflow pipes to the hillslope, packers will be installed in each well outflow pipe.

As noted in Sect. 4, pre-construction drawings indicate that the drainage pipes in the tank excavations may be placed several inches above the bottom of the excavations, possibly allowing a volume of liquid to accumulate in the excavation before flowing into the well. It is assumed that the wells are closed-bottomed pipes and that any liquid collecting below the level of the drainage pipe could not be pumped out of the dry well. Table 5.2 shows the significant volumes of liquid that might be recovered from the dry wells in the event of a tank failure. It compares the well recovery volumes to the volumes of liquid expected to be in each tank at the start of the first sluice pass and the volumes of liquid that may collect in the excavations beneath the drainage pipes (excavation holding capacity). The recovery volumes assume that the excavations are currently empty and that they would fill to the level of the drainage pipes before flowing into the wells.

Table 5.2. Tank leakage recovery volumes

\begin{tabular}{cccc}
\hline Tank & $\begin{array}{c}\text { Possible well recovery } \\
\text { volume } \\
\text { (gal) }\end{array}$ & $\begin{array}{c}\text { Volume of tank contents } \\
\text { (gal) }\end{array}$ & $\begin{array}{c}\text { Excavation holding } \\
\text { capacity } \\
\text { (gal) }\end{array}$ \\
\hline T-1 & 2,164 & 3,304 & 1,140 \\
T-2 & 4,067 & 4,997 & 930 \\
T-3 & 7,094 & 8,384 & 1,290 \\
T-4 & 4,203 & 5,493 & 1,290 \\
T-9 & 674 & 2,024 & 1,350 \\
\hline
\end{tabular}

${ }^{a}$ Assumes total loss of tank contents and assumes excavation contains no liquid before leak from tank.

${ }^{b}$ Expected volume of tank contents at start of first sluice pass.

' Based on calculations provided in Appendix $A$.

\subsubsection{Tank Overflow Mitigation}

If a tank overflow is detected, the situation will be immediately corrected by shutting down the pump, if liquid is being pumped into the system, or shutting off the process water valve, and 
responding with the spill control kit. The pumps and the process water valves can be controlled remotely from the control trailer.

A spill control kit containing absorbent materials, shovels, a drum, and appropriate personal protective equipment will be maintained on-site and any spill will be cleaned up immediately, following precautions specified by the Site Safety and Health Officer.

\subsubsection{Waste Transfer Pipeline Leak Mitigation}

If a leak is detected in the waste transfer pipeline, the pump (high pressure) will be shut off immediately and the valve controlling flow to the pipeline will be shut off. Pumping will not resume until the line is repaired. Precautions will be taken to avoid spilling residual supernatant during maintenance on the line.

Any necessary spill cleanup will proceed as specified in Sect. 5.2.3.

\subsubsection{Sluice Equipment Leak or Spill Mitigation}

Any necessary spill cleanup will proceed as specified in Sect. 5.2.3.

\subsection{REPORTING REQUIREMENTS}

The health and safety plan developed for the sluicing and pumping project will detail the procedure for reporting health and safety issues. In addition, emergencies and other reportable occurrences should be reported in accordance with Eneregy Systems procedure OP-301, "Occurrence Notification and Reporting." 


\section{REFERENCES}

DOE (U.S. Department of Energy) 1994. U.S. Department of Energy, Radiological Control Manual. DOE/EH-0256T, Revision 1, April.

Energy Systems (Martin Marietta Energy Systems, Inc.) 1994. X-10 Site Emergency Plan. ORNL/CF-91/71/R2, September.

Energy Systems (Lockheed Martin Energy Systems, Inc.) 1996a. Basis for Interim Operation, Facility 7852, Old Hydrofracture Facility. ORNL/BIO/7852/ER/R1.

Energy Systems (Lockheed Martin Energy Systems, Inc.) 1996b. Conceptual Site Model for Risk Assessment for the OHF Tanks. ORNL-DWG 96M-5312.

Energy Systems (Lockheed Martin Energy Systems, Inc.) 1996c. Preliminary Engineering Report, Old Hydrofracture Facility, Tanks Content Removal Project. ORNL/ER-372.

Energy Systems (Lockheed Martin Energy Systems, Inc.) 1996d. Site Characterization Summary Report for the Old Hydrofracture Facility, Waste Area Grouping 5, at Oak Ridge National Laboratory, Oak Ridge, Tennessee. ORNL/ER-360.

Kincaid, J.H., 1993. A Method for Evaluating the Structural Integrity of Buried Liquid Low-Level Waste Tanks. Presented at the 1993 Symposium on Waste Management of the American Nuclear Society.

STEP in preparation. Structural Integrity Assessment for Installation of Tank Risers at the Old Hydrofracture Tanks (Draft). 
Appendix A

CALCULATED HOLDING CAPACITIES OF OHF TANK DRAINAGE BEDS 


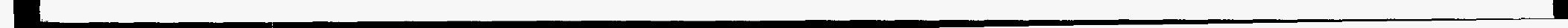

\begin{tabular}{|} 
\\
\\
\\
\end{tabular} 


\section{CALCULATED HOLDING CAPACITIES OF OHF TANK DRAINAGE BEDS}

Following are calculations of the holding capacities of the OHF tank drainage beds-the volume of material that would potentially be held in the drainage beds, rather than flowing into the dry wells. The basis for the calculations are pre-construction drawings showing the cell drainage pipes placed several inches above the bottom of the excavations [ORNL drawings E-004$D$ (1963) and EE-042-D (Energy Systems 1966b)]. As-built drawings confirming this construction have not been located. It is assumed that the porosity of the gravel and the crushed stone backfill material is $50 \%$ and that the sides of the excavations are vertical.

\section{Tank T-1 drainage bed}

$46 \mathrm{ft}$ length $\times 11.5 \mathrm{ft}$ width $\times 0.583 \mathrm{ft}(7 \mathrm{in}$.$) height =308 \mathrm{ft}^{3}$

$308 \mathrm{ft}^{3} \times 7.4 \mathrm{gal} / \mathrm{ft}^{3} \times 50 \%$ porosity $=1140$ gal holding capacity

Tank T-2 drainage bed

$46 \mathrm{ft} \times 9.25 \mathrm{ft}$ width $\times 0.583 \mathrm{ft}(7$ in. $)$ height $=248 \mathrm{ft}^{3}$

$248 \mathrm{ft}^{3} \times 7.48 \mathrm{gal} / \mathrm{ft}^{3} \times 50 \%$ porosity $=930$ gal holding capacity

\section{Tank T-9 drainage bed}

$46 \mathrm{ft}$ length $\times 13.5 \mathrm{ft}$ width $\times 0.583 \mathrm{ft}\left(7\right.$ in.) height $=362 \mathrm{ft}^{3}$

$362 \mathrm{ft}^{3} \times 7.48 \mathrm{gal} / \mathrm{ft}^{3} \times 50 \%$ porosity $=1350$ gal holding capacity

Tanks T-3/T-4 drainage bed

$42.6 \mathrm{ft}$ minimum ${ }^{a}$ length $\times 24.5 \mathrm{ft}$ minimum width $\times 0.33 \mathrm{ft}(4 \mathrm{in}$.$) height =344 \mathrm{ft}^{3}$

$344 \mathrm{ft}^{3} \times 7.48 \mathrm{gal} / \mathrm{ft}^{3} \times 50 \%$ porosity $=1290 \mathrm{gal}$ holding capacity

${ }^{a}$ The dimensions of the T-3/T-4 excavation are not shown on available drawings. Therefore, the minimum possible dimensions, given the dimensions of the tanks, were used in calculating the holding capacity of the drainage bed. For the length, the length of the tanks was used. To estimate the minimum width, the distance between the tanks was added to the widths of the tanks. 


\section{DISTRIBUTION}

1. L. V. Asplund

2. J. F. Alexander

3. C. A. Bednarz

4. J. E. Francis

5. J. R. Farmer

6. D. L. Garrett

7. A. J. Kuhaida, Jr.

8. D. M. Matteo

9. P. T. Owen

10. J. H. Platfoot

11. S. T. Rudell

12. R. B. Scott

13. R. L. Sherles, Jr.

14. P. A. Schrandt

15. A. W. Saulsbury

16. M. F. Tardiff

17. M. L. Whitehead

18. Central Research Library

19. ER Document Management Center-RC

20. C. L. Callis, CDM Federal Programs Corporation, 800 Oak Ridge Turnpike, Suite 500, Oak Ridge, Tennessee 37830

21. C. A. Provost, CDM Federal Programs Corporation, 800 Oak Ridge Turnpike, Suite 500, Oak Ridge, Tennessee 37830

22. Office of Scientific and Technical Information, P.O. Box 62, Oak Ridge, TN 37831 